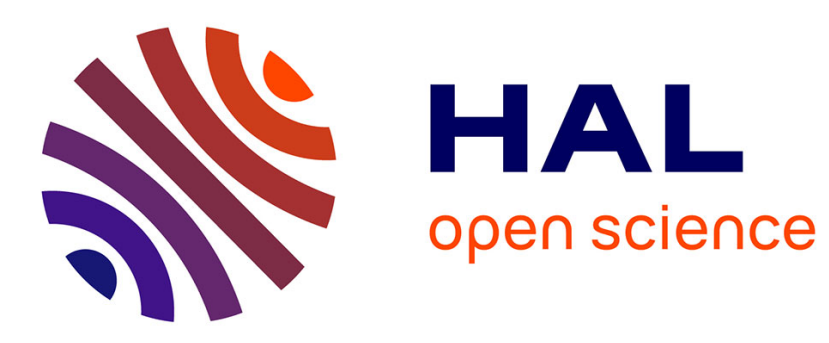

\title{
Effect of coordination dissymmetry on the catalytic activity of manganese catalase mimics
}

\author{
Ripul Mehrotra, Micaela Richezzi, Claudia Palopoli, Christelle Hureau, \\ Sandra Signorella
}

\section{- To cite this version:}

Ripul Mehrotra, Micaela Richezzi, Claudia Palopoli, Christelle Hureau, Sandra Signorella. Effect of coordination dissymmetry on the catalytic activity of manganese catalase mimics. Journal of Inorganic Biochemistry, 2020, 213, pp.111264. 10.1016/j.jinorgbio.2020.111264 . hal-03025390

\section{HAL Id: hal-03025390 https://hal.science/hal-03025390}

Submitted on 26 Nov 2020

HAL is a multi-disciplinary open access archive for the deposit and dissemination of scientific research documents, whether they are published or not. The documents may come from teaching and research institutions in France or abroad, or from public or private research centers.
L'archive ouverte pluridisciplinaire HAL, est destinée au dépôt et à la diffusion de documents scientifiques de niveau recherche, publiés ou non, émanant des établissements d'enseignement et de recherche français ou étrangers, des laboratoires publics ou privés. 


\section{Effect of Coordination Dissymmetry on the Catalytic Activity of Manganese}

Catalase Mimics

Ripul Mehrotra, ${ }^{\mathrm{a}, 1}$ Micaela Richezzi, ${ }^{a}$ Claudia Palopoli, ${ }^{a}$ Christelle Hureau, ${ }^{\mathrm{b}}$ and Sandra R. Signorella ${ }^{\mathrm{a}, *}$

aQUIR (Instituto de Quimica Rosario), Consejo Nacional de Investigaciones Cientificas y Tecnicas (CONICET), Facultad de Ciencias Bioquimicas y Farmaceuticas, Universidad Nacional de Rosario, Suipacha 531, S2002LRK Rosario, Argentina

${ }^{b}$ CNRS, LCC (Laboratoire de Chimie de Coordination) and UPS, INPT, LCC, Université de Toulouse, 205 route de Narbonne, F-31077 Toulouse, France

${ }^{*}$ Corresponding author: signorella@iquir-conicet.gov.ar

${ }^{1}$ Present address: Department of chemistry, Govt. College Chhapara, District-Seoni, Madhya Pradesh, India. 


\section{Abstract}

Two mixed-valence $\mathrm{Mn}(\mathrm{II}) \mathrm{Mn}(\mathrm{III})$ complexes, $\left[\mathrm{Mn}_{2} \mathrm{~L}^{1}(\mathrm{OAc})_{2}\left(\mathrm{H}_{2} \mathrm{O}\right)\right] \mathrm{BPh}_{4} \cdot 2.5 \mathrm{H}_{2} \mathrm{O}$ and $\left[\mathrm{Mn}_{2} \mathrm{~L}^{2}(\mathrm{OAc})_{2}\right] \cdot 4 \mathrm{H}_{2} \mathrm{O}$, obtained with unsymmetrical $\mathrm{N}_{4} \mathrm{O}_{2}$-hexadentate $\mathrm{L}^{1(2-)}\left(\mathrm{H}_{2} \mathrm{~L}^{1}=2-(\mathrm{N}, \mathrm{N}-\right.$ bis(2-(pyridylmethyl)aminomethyl)-6-(N-(2-hydroxybenzyl)benzylaminomethyl)-4methylphenol) and $\mathrm{N}_{4} \mathrm{O}_{3}$-heptadentate $\quad \mathrm{L}^{2(3-)} \quad\left(\mathrm{NaH}_{2} \mathrm{~L}^{2}=2-(\mathrm{N}, \mathrm{N}-\mathrm{bis}(2-\right.$ (pyridylmethyl)aminomethyl)-6-(N'-(2-hydroxybenzyl)(carboxymethyl)aminomethyl)-4methylphenol sodium salt) ligands, have been prepared and characterized. Both complexes share a $\mu$-phenolate-bis $\left(\mu\right.$-acetate) $\mathrm{Mn}(\mathrm{II}) \mathrm{Mn}(\mathrm{III})$ core and $\mathrm{N}_{3} \mathrm{O}_{3}$-coordination sphere around the $\mathrm{Mn}(\mathrm{II})$ ion, but differ in the donor groups surrounding $\mathrm{Mn}(\mathrm{III})\left(\mathrm{NO}_{4}\right.$ (solvent) and $\mathrm{NO}_{5}$ ). In nonprotic solvents, these two complexes are able to disproportionate at least 3600 equiv. of $\mathrm{H}_{2} \mathrm{O}_{2}$ without significant decomposition, with first-order dependence on catalyst and saturation kinetics on $\left[\mathrm{H}_{2} \mathrm{O}_{2}\right]$. Spectroscopic monitoring of the reaction mixtures revealed the two complexes disproportionate $\mathrm{H}_{2} \mathrm{O}_{2}$ employing a different redox cycle, with retention of dinuclearity. The higher catalytic efficiency of $\left[\mathrm{Mn}_{2} \mathrm{~L}^{2}(\mathrm{OAc})_{2}\right]$ was rationalized in terms of the larger labilizing effect of the heptadentate ligand that favors the acetate-shift and the replacement of the non-coordinating benzyl arm of $L^{1}$ by a carboxylate arm in $L^{2}$ which facilitates the formation of the catalyst $-\mathrm{H}_{2} \mathrm{O}_{2}$ adduct, placing $\left[\mathrm{Mn}_{2} \mathrm{~L}^{2}(\mathrm{OAc})_{2}\right]$ as the most efficient among the phenolate-bridged diMn catalysts based on the $\mathrm{k}_{\mathrm{cat}} / \mathrm{K}_{\mathrm{M}}$ criterion.

\section{Keywords}

Biomimics; diMn complexes; unsymmetrical ligands; CAT activity; mechanism; spectroscopy 


\section{Introduction}

$\mathrm{H}_{2} \mathrm{O}_{2}$ is a by-product of aerobic metabolism in respiratory and photosynthetic electron-transport chains and a product of enzymatic activity [1]. Excess of $\mathrm{H}_{2} \mathrm{O}_{2}$ and hydroxyl radical, its decomposition product formed via a Fenton-type reaction, are harmful for almost all cell components. Thus, the rapid and efficient removal of $\mathrm{H}_{2} \mathrm{O}_{2}$ is essential to all aerobically living prokaryotic and eukaryotic cells. Catalase (CAT) enzymes are present in most aerobic forms of life and are responsible for the decomposition of $\mathrm{H}_{2} \mathrm{O}_{2}$ into molecular oxygen and water [2]. In many pathological conditions and diseases, including cancer, neurological disorders, atherosclerosis, hypertension, ischemia/perfusion, diabetes, etc., the endogenous antioxidant systems can be overwhelmed. Administration of exogenous enzymes for the treatment of oxidative stress is limited by their short half-life, antigenicity, high cost, and large sizes that disable the enzymes to cross the cell membranes [3,4]. Therefore, low molecular weight enzyme mimics constitute an alternative to overcome these limitations [5-7], some of which have proven to protect cells from oxidative damage in animal models [8].

Manganese catalases (MnCAT) contain two $\mathrm{Mn}$ ions at their active site and catalyze the disproportionation of $\mathrm{H}_{2} \mathrm{O}_{2}$ through a $\mathrm{Mn}(\mathrm{II})_{2}$ and $\mathrm{Mn}(\mathrm{III})_{2}$ redox cycle [9-11]. The two metal ions of the diMn active site are triply bridged through a $\mu_{1,3}$-carboxylate of a glutamate residue and two solvent-derived bridges (either aqua, hydroxo, or oxo ligands) and terminally bound to His and Glu $[12,13]$. Both Mn subsites are six-coordinate but only one of them is bound to a labile water molecule where initial substrate binding is presumed to occur. This coordination dissymmetry around the two metal ions could be essential for catalysis. However, most diMn complexes tested as MnCAT mimics have been prepared with symmetrical dinucleating ligands with a central alcoholate or phenolate group that afford synthetic models with identical environment around the two metal centers [14-18], while only a few ones were made from unsymmetrical ligands [19-21].

With the aim of reproducing the singularities of the biosite, we report here the synthesis, properties and CAT activity of two diMn complexes obtained with unsymmetrical ligands bearing a central phenolate group: 2-(N,N-bis(2-(pyridylmethyl)aminomethyl)-6-( $\mathrm{N}-(2-$ 
hydroxybenzyl)benzylaminomethyl)-4-methylphenol $\quad\left(\mathrm{H}_{2} \mathrm{~L}^{1}\right) \quad$ and $\quad$ 2-(N,N-bis(2(pyridylmethyl)aminomethyl)-6-(N'-(2-hydroxybenzyl)(carboxymethyl)aminomethyl)-4methylphenol sodium salt $\left(\mathrm{NaH}_{2} \mathrm{~L}^{2}\right)$, and compare the kinetic results to other diMn mimics. These ligands offer two different coordination compartments to build bimetallic sites with different environment around each metal center and will be used for assessing the influence of the ligand dissymmetry on the CAT activity of the diMn complexes.

\section{Experimental part}

\subsection{Synthesis of the ligands}

The secondary amines, bis(2-pyridylmethyl)amine, $\mathrm{N}$-(2-hydroxybenzyl)benzylamine and $\mathrm{N}$ (2-hydroxybenzyl)glycine chlorohydrate were prepared as reported previously [22-24]. Intermediates (6-Methyl-2-phenyl-2,4-dihydro-1,3-benzodioxin-8-yl)methanol (1), 8(bromomethyl)-6-methyl-2-phenyl-2,4-dihydro-1,3-benzodioxine $\quad$ (2), 8-(bis(2pyridylmethyl)aminomethyl)-6-methyl-2-phenyl-2,4-dihydro-1,3-benzodioxine (3), 2(N,N-bis(2-(pyridylmethyl)aminomethyl)-6-(hydroxymethyl)-4-methylphenol (4) and 2-(N,Nbis(2-(pyridylmethyl)aminomethyl)-6-(chloromethyl)-4-methylphenol (5), were synthesized following procedures described in references $[23,25-27]$. Synthetic details for the obtention of these compounds are described in the supplementary information.

2.1.1. 2-(N,N-Bis(2-(pyridylmethyl)aminomethyl)-6-(N-(2-hydroxybenzyl)benzylaminomethyl)4-methylphenol $\left(\boldsymbol{H}_{2} \boldsymbol{L}^{1}\right)$. To a solution of $\mathbf{5}(533.6 \mathrm{mg}, 1.45 \mathrm{mmoL})$ and $\mathrm{N}-(2-$ hydroxybenzyl)benzylamine (309 mg, $1.45 \mathrm{mmoL}$ ) dissolved in THF (15 mL), $200 \mu \mathrm{L}$ of $\mathrm{Et}_{3} \mathrm{~N}$ were added and left with stirring at room temperature for 6 days. The solid formed was removed by filtration. After evaporation of THF, a red yellow oil was obtained. This oil was further dissolved in $5 \mathrm{~mL} \mathrm{CH}_{2} \mathrm{Cl}_{2}$ and washed with phosphate buffer (pH 7.0). The organic layers were collected, dried over $\mathrm{Na}_{2} \mathrm{SO}_{4}$ and filtered. After solvent evaporation the solid product was obtained. Yield: $380.2 \mathrm{mg}, 48.1 \% .{ }^{1} \mathrm{H}$ NMR spectrum $\left(\delta, \mathrm{CDCl}_{3}, \mathrm{ppm}\right): 8.56$ (d, $\left.2 \mathrm{H}, \mathrm{Ar}-\mathrm{H}_{\mathrm{py}}\right) ; 7.60-7.54(\mathrm{td}, 2 \mathrm{H}, \mathrm{Ar}-\mathrm{H}) ; 7.45(\mathrm{~d}, 1 \mathrm{H}, \mathrm{Ar}-\mathrm{H}) ; 7.36-7.31$ (m, 5H, Ar-H); 7.28-7.24 (m, 1H, Ar-H); 7.16-7.12 (t, 2H, Ar-H); 7.10-7.09 (m,1H, Ar-H); 6.99-6.97 (d, 1H, Ar-H); 6.91 


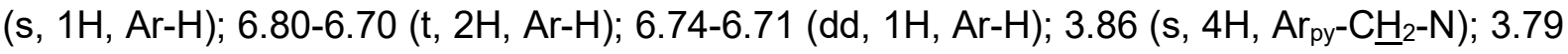
(s, 2H, $\left.-\mathrm{CH}_{2}\right) ; 3.74\left(\mathrm{~s}, 2 \mathrm{H},-\mathrm{CH}_{2}\right) ; 3.72\left(\mathrm{~s}, 2 \mathrm{H},-\mathrm{CH}_{2}\right) ; 3.68\left(\mathrm{~s}, 2 \mathrm{H},-\mathrm{CH}_{2}\right) ; 2.22\left(\mathrm{~s}, 3 \mathrm{H}, \mathrm{CH}_{3}\right) .{ }^{13} \mathrm{C}$ NMR spectrum $\left(\delta, \mathrm{CDCl}_{3}, \mathrm{ppm}\right): 158.23,157.7,154.15,148.92,136.73,131.42,130.44$, $129.71,128.90,128.41,128.30,127.46,127.24,126.55,123.27,122.67,122.18,118.82$ 115.98, 59.16, 57.93, 57.13, 56.70, 20.43. Significant IR bands (ATR, $\left.v \mathrm{~cm}^{-1}\right): 3356,2914$, 1589, 1454, 1433, 1357, 746, 696.

\subsubsection{2-(N,N-Bis(2-(pyridylmethyl)aminomethyl)-6-(N'-(2-hydroxybenzyl)(carboxymethyl)} aminomethyl)-4-methylphenol sodium salt $\left(\mathrm{NaH}_{2} \mathrm{~L}^{2}\right)$. A solution of $5(1.36 \mathrm{mmol}, 500 \mathrm{mg})$ in 15 $\mathrm{mL}$ THF was added to N-(2-hydroxybenzyl)glycine chlorohydrate (296 mg, $1.36 \mathrm{mmol})$ in $5 \mathrm{~mL}$ of $0.55 \mathrm{M} \mathrm{NaOH}$ aqueous solution. The mixture was left with stirring for $48 \mathrm{~h}$. THF was removed under vacuum and $20 \mathrm{~mL} \mathrm{CH}_{2} \mathrm{Cl}_{2}$ added to the aqueous residue. The organic layer was separated and washed with phosphate buffer of pH $7.0(3 \times 10 \mathrm{~mL})$, dried over $\mathrm{Na}_{2} \mathrm{SO}_{4}$ and filtered. After concentration of the filtrate, hexane was added and a yellow solid formed when cooled at $4^{\circ} \mathrm{C}$. Recrystallization from $2: 8 \mathrm{CHCl}_{3}$ :hexane mixture afforded a bright yellow solid. Yield: $139 \mathrm{mg}(19.2 \%) .{ }^{1} \mathrm{H}$ NMR spectrum ( $\delta$, MeOD, ppm): 8.49 (d, $\left.1 \mathrm{H}, \mathrm{Ar}-\mathrm{H}_{\mathrm{Py}}\right), 8.38$ (d, $1 \mathrm{H}$, Ar- $\left.\mathrm{H}_{\text {Py }}\right), 7.69(\mathrm{dt}, 1 \mathrm{H}, \mathrm{Ar}-\mathrm{H}), 7.61(\mathrm{dt}, 1 \mathrm{H}, \mathrm{Ar}-\mathrm{H}), 7.39(\mathrm{~m}, 2 \mathrm{H}, \mathrm{Ar}-\mathrm{H}), 7.23(\mathrm{~m}, 2 \mathrm{H}, \mathrm{Ar}-\mathrm{H}), 7.02$ (m, 2H, Ar-H), $6.85(\mathrm{~m}, 2 \mathrm{H}, \mathrm{Ar}-\mathrm{H}), 6.78(\mathrm{~s}, 2 \mathrm{H}, \mathrm{Ar}-\mathrm{H}), 3.84$ (s, 4H, $\left.\operatorname{Ar}_{p y}-\mathrm{C}_{2}-\mathrm{N}\right), 3.74(\mathrm{~s}, 2 \mathrm{H},-$ $\left.\mathrm{CH}_{2}-\right), 3.72\left(\mathrm{~s}, 2 \mathrm{H}, \mathrm{CH}_{2}\right), 3.68\left(\mathrm{~s}, 2 \mathrm{H}, \mathrm{CH}_{2}\right), 3.56\left(\mathrm{~s}, 2 \mathrm{H},-\mathrm{C}_{2}-\mathrm{CO}_{2}\right), 2.23\left(\mathrm{~s}, 3 \mathrm{H}, \mathrm{CH}_{3}\right) .{ }^{13} \mathrm{C} \mathrm{NMR}$ spectrum ( $\delta$, MeOD, ppm): 168.93, 157.96, 157.92, 156.45, 154.03, 148.22, 148.01, 137.44, $137.22,132.73,131.75,131.17,128.29,128.06,127.57,123.68,123.51,123.45,123.18$ $122.44,122.40,119.62,115.12,59.34,58.64,58.28,58.12,56.40,55.90,54.85,54.32,18.94$. Significant IR bands (ATR, $\left.v \mathrm{~cm}^{-1}\right): 3420,2075,3010,2917,2847,1636,1591,1435,1381$, $862,760$.

\subsection{Synthesis of complexes}

2.2.1. Complex $\left[\mathrm{Mn}_{2} \mathrm{~L}^{1}(\mathrm{OAc})_{2}\left(\mathrm{H}_{2} \mathrm{O}\right)\right] B P h_{4} \cdot 2.5 \mathrm{H}_{2} \mathrm{O}\left(\mathbf{6} \cdot 2.5 \mathrm{H}_{2} \mathrm{O}\right)$. A solution of $\mathrm{H}_{2} \mathrm{~L}^{1}(113.2 \mathrm{mg}$, $0.208 \mathrm{mmoL})$ in $\mathrm{CH}_{3} \mathrm{OH}(2 \mathrm{~mL})$ was added to a methanolic solution of manganese(II) acetate tetrahydrate (102 $\mathrm{mg}, 0.416 \mathrm{mmoL})$ and left with stirring at room temperature for $2 \mathrm{~h}$. The addition of a methanolic solution $(2 \mathrm{~mL})$ of $\mathrm{NaBPh}_{4}(71.1 \mathrm{mg})$ caused the formation of a brown 
precipitate, which was collected by filtration, washed with methanol and hexane and dried under vacuum. Yield: $0.1920 \mathrm{~g}(0.167 \mathrm{mmol}), 80.0 \%$. Thin layer chromatography (TLC) of 6 using different mobile phases (in different ratios) and three different stationary phases (silica, alumina and cellulose) showed only one spot. Anal. calcd. for $\mathrm{BC}_{63} \mathrm{H}_{62} \mathrm{Mn}_{2} \mathrm{~N}_{4} \mathrm{O}_{7} \cdot 2.5 \mathrm{H}_{2} \mathrm{O}$ : C 65.6, H 5.9, Mn 9.5, N 4.9, \%; Found: C 65.5, H 5.6, Mn 9.2, N $5.3 \%$. Molar conductivity $\left(\mathrm{CH}_{3} \mathrm{OH}\right)=129 \Omega^{-1} \mathrm{~cm}^{2} \mathrm{~mol}^{-1}$. UV-vis, $\lambda_{\max } \mathrm{nm}\left(\varepsilon \mathrm{M}^{-1} \mathrm{~cm}^{-1}\right)$ in $N, N$-dimethylformamide (DMF): 275 (20800), 365 (4168), 450 (sh), 608 (264). Significant IR bands $\left(\mathrm{KBr}, v \mathrm{~cm}^{-1}\right)$ : 3445 (broad), $3055,3030,2920,2853,1625,1595,1560,1431,864,734,705,644,611$. The content of 2.5 molecules of non-coordinated water per complex molecule was confirmed by thermogravimetric analysis of the complex which showed $3.9 \%$ mass loss below $120{ }^{\circ} \mathrm{C}$.

2.2.2. Complex $\left[\mathrm{Mn}_{2} \mathrm{~L}^{2}(\mathrm{OAc})_{2}\right] \cdot 4 \mathrm{H}_{2} \mathrm{O}\left(\mathbf{7} \cdot 4 \mathrm{H}_{2} \mathrm{O}\right)$. A solution of $\mathrm{NaH}_{2} \mathrm{~L}^{2}(100 \mathrm{mg}, 0.187 \mathrm{mmol})$ in $8 \mathrm{~mL} \mathrm{CH} \mathrm{CH}_{3} \mathrm{OH}$ was mixed with a solution of $\mathrm{Mn}(\mathrm{OAc})_{2} \cdot 4 \mathrm{H}_{2} \mathrm{O}(92 \mathrm{mg}, 0.378 \mathrm{mmol})$ in $2 \mathrm{~mL}$ $\mathrm{CH}_{3} \mathrm{OH}$, and the red brown mixture was left with stirring for $3 \mathrm{~h}$. Then the volume was reduced to $2 \mathrm{~mL}$ under vacuum, $10 \mathrm{~mL}$ ethyl ether were added, and the mixture cooled to $4^{\circ} \mathrm{C}$. After 3 h, the formed brown precipitate was filtered off, washed with cool $\mathrm{CH}_{3} \mathrm{OH}$ and ether and dried under vacuum. Yield: $108 \mathrm{mg}, 78.3 \%$. TLC of 7 using different mobile phases (in different ratios) and three different stationary phases (silica, alumina and cellulose) showed only one spot. Anal. calcd. for $\mathrm{C}_{34} \mathrm{H}_{35} \mathrm{Mn}_{2} \mathrm{~N}_{4} \mathrm{O}_{8} \cdot 4 \mathrm{H}_{2} \mathrm{O}$ : C 50.4, H 5.4, Mn 13.6, N 6.9, \%; Found: C 50.1, H 5.1, Mn 13.7, N 6.7 \%. UV-vis, $\lambda_{\max } \mathrm{nm}\left(\varepsilon \mathrm{M}^{-1} \mathrm{~cm}^{-1}\right)$ in DMF: 279 (21350), 345 (4105), 462 (1665), 694 (293). Significant IR bands $\left(\mathrm{KBr}, v \mathrm{~cm}^{-1}\right)$ : 3435 (broad), 3065, 3032, 3004, 2921, $2859,1624,1590,1574,1422,806,761,654,630$. The content of 4 molecules of noncoordinated water per complex molecule was confirmed by thermogravimetric analysis of the complex which showed $8.9 \%$ mass loss below $120^{\circ} \mathrm{C}$.

\subsection{Analytical and physical measurements}

Infrared spectra were recorded on a Perkin-Elmer Spectrum One FTIR spectrophotometer in the 4000-400 $\mathrm{cm}^{-1}$ range. UV-visible spectra were recorded on a Jasco V-550 spectrophotometer, with thermostated cell compartments. Metal content was determined with an Inductively coupled plasma mass spectrometer (ICP-MS) Perkin Elmer NexION 350X. EPR 
spectra were obtained at $115 \mathrm{~K}$ on an Elexsys E 500 Bruker spectrometer, operating at a microwave frequency of approximately $9.5 \mathrm{GHz}$. TGA measurements were conducted on a Perkin-Elmer Diamond TG/DTA Instrument. The compound was heated at the rate of 10 ${ }^{\circ} \mathrm{C} /$ min between $\mathrm{RT}$ and $800^{\circ} \mathrm{C}$. Conductivity measurements were performed using a Horiba F-54 BW conductivity meter, on $1.0 \mathrm{mM}$ solutions of the complexes in methanol. Electrospray ionization (ESI) mass spectra were obtained with a Thermo Scientific LCQ Fleet. The solutions for electrospray were prepared from solutions of complex or reaction mixtures diluted with acetonitrile to a final $\sim 10^{-5} \mathrm{M}$ concentration. ${ }^{1} \mathrm{H}$ NMR spectra were recorded on a Bruker $\mathrm{AC}$ 300 NMR spectrometer at ambient probe temperature (ca. $25^{\circ} \mathrm{C}$ ). Chemical shifts (in ppm) are referenced to tetramethylsilane and paramagnetic NMR spectra were acquired employing superWEFT sequence, with acquisition time of $50 \mathrm{~ms}$. The electrochemical experiments were performed with a computer-controlled Princeton Applied Research potentiostat, VERSASTAT II model, with the 270/250 Research Electrochemistry Software. Studies were carried out under $\mathrm{Ar}$, in DMF solution using $0.1 \mathrm{M} \mathrm{Bu}_{4} \mathrm{NPF}_{6}$ as a supporting electrolyte and $\approx 10^{-3} \mathrm{M}$ of the complexes. The working electrode was a glassy carbon disk, and the reference electrode was a calomel electrode isolated in a fritted bridged with a Pt wire as the auxiliary electrode. All potentials are referred to the SCE electrode. Under these conditions, $E$ (ferrocene/ferrocenium) $=474 \mathrm{mV}$, in DMF.

\subsection{Evaluation of CAT activity}

Reaction rates were determined by volumetric measurement of the $\mathrm{O}_{2}$ evolved after addition of excess of $\mathrm{H}_{2} \mathrm{O}_{2}$ to a DMF solution of the complex. A round-bottom flask with a rubber septum, containing the degassed solution of the complex, was thermostated at $25^{\circ} \mathrm{C}$ and connected to a gas-measuring burette (precision of $0.1 \mathrm{~mL}$ ). Previously thermostated $\mathrm{H}_{2} \mathrm{O}_{2}$ was injected through the septum to the stirred complex solution, and the evolved $\mathrm{O}_{2}$ was measured with the burette. The initial reaction rates were obtained by fitting the $\left[\mathrm{O}_{2}\right]$ versus time data to a polynomial expression and calculating the slope of the tangent at time zero. Each rate constant reported here represents the mean value of multiple determinations that fall within $\pm 5 \%$. All 
experiments were carried out at $25^{\circ} \mathrm{C}$. Blanc experiments performed with $100 \mathrm{mM} \mathrm{H}_{2} \mathrm{O}_{2}$ in DMF without the catalyst showed no decomposition after $1 \mathrm{~h}$.

\section{Results and discussion}

\subsection{Synthesis and characterization of complexes 6 and 7}

The synthesis of the unsymmetrical ligands $\mathrm{H}_{2} \mathrm{~L}^{1}$ and $\mathrm{NaH}_{2} \mathrm{~L}^{2}$ is shown in Scheme 1.<smiles>CC#CCc1cc(C)cc(CO)c1OC(CO)C(C)C</smiles>

1<smiles>Cc1cc(CBr)c2c(c1)COC(c1ccccc1)O2</smiles>

2<smiles>NCCCc1ccccn1</smiles>

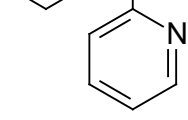<smiles>CC=CC</smiles>

3<smiles>Cc1cc(CN)c(O)c(CCl)c1</smiles><smiles>Cc1cc(CN(Cc2ccccc2)Cc2ccccn2)c(O)c(CN(Cc2ccccc2)Cc2ccccc2O)c1</smiles>

$\mathrm{H}_{2} \mathrm{~L}^{1}$<smiles>CCCCc1cccc(CN(Cc2ccccn2)Cc2cc(C)cc(CN(CC(=O)O[Na])Cc3ccccc3O)c2O)n1</smiles>

$\mathrm{NaH}_{2} \mathrm{~L}^{2}$

Scheme 1. Synthesis of unsymmetrical ligands. (i) $\mathrm{PhCH}(\mathrm{OMe})_{2}, \mathrm{p}-\mathrm{MeC}_{6} \mathrm{H}_{4} \mathrm{SO}_{3} \mathrm{H}, \mathrm{DMF}, 50^{\circ} \mathrm{C}$; (ii) $\mathrm{CBr}_{4}$, $\mathrm{PPh}_{3}$, DMF; (iii) $\mathrm{NaH}, \mathrm{CH}_{2} \mathrm{Cl}_{2}$; (iv) $\mathrm{HCl}, \mathrm{THF}, 0^{\circ} \mathrm{C}$; (v) $\mathrm{Cl}_{2} \mathrm{SO}, 35^{\circ} \mathrm{C}$; (vi) $\mathrm{Et}_{3} \mathrm{~N}, \mathrm{THF}$; (vii) $\mathrm{NaOH}, \mathrm{THF}$ 
The key step in the synthesis for introduction of dissymmetry is the formation of the cyclic acetal 1 to protect one of the terminal hydroxymethyl groups of the starting 2,6bis(hydroxymethyl)-4-methylphenol [25]. Next, bromination and alkylation of bis-2-picolylamine afforded the $\mathrm{N}_{3}$-branch. Acid hydrolysis of the acetal, followed by chlorination and subsequent alkylation of a second amine bearing terminal benzyl/phenol or carboxylate/phenol groups afforded the $\mathrm{N}_{4} \mathrm{O}_{2}$-hexadentate $\left(\mathrm{H}_{2} \mathrm{~L}^{1}\right)$ and $\mathrm{N}_{4} \mathrm{O}_{3}$-heptadentate $\left(\mathrm{H}_{2} \mathrm{NaL}^{2}\right)$ ligand, respectively.

Dimanganese complexes 6 and 7 were prepared from 1:2 mixtures of the corresponding ligand and $\mathrm{Mn}(\mathrm{OAc})_{2} \cdot 4 \mathrm{H}_{2} \mathrm{O}$ in methanol. Acetate facilitates the deprotonation of the ligand for coordination to the metal [28] and complexation occurs immediately after mixing, as evidenced by the change of color of the reaction mixture from pale yellow to brown. Complex 6 was precipitated as a brown solid from the reaction mixture upon addition of the bulky $\mathrm{BPh}_{4}{ }^{-}$, while complex 7 separated from the solution as a brown solid after addition of ether at $4{ }^{\circ} \mathrm{C}$.

The IR spectra of powdered 6 and 7 (Figure S1) exhibit strong phenolate and pyridyl ring absorptions between 1625 and $1575 \mathrm{~cm}^{-1}$ as well as absorption bands at $1560-1574 \mathrm{~cm}^{-1}$ and $1431-1422 \mathrm{~cm}^{-1}$ attributable to the antisymmetrical and symmetrical stretching vibrations of carboxylate groups. For 6 , the three bands at 611,705 and $734 \mathrm{~cm}^{-1}$ together with a strong and sharp stretching band at $\sim 3055 \mathrm{~cm}^{-1}$ can be assigned to non-coordinated $\mathrm{BPh}_{4}{ }^{-}$counter anion, in agreement with its molecular structure. In line with the loss of $\mathrm{H}_{2} \mathrm{O}$ evidenced by the thermogravimetric analysis, the two compounds display a broad band at $\approx 3440 \mathrm{~cm}^{-1}$ assigned to water molecules.

ESI-mass spectra of complexes 6 and 7 in $\mathrm{CH}_{3} \mathrm{CN}$ (Figure 1(a)) confirmed their chemical composition as well as retention of their nuclearity in solution. For complex $\mathbf{6}$, the parent peak is observed at $\mathrm{m} / \mathrm{z}=811.2$ in the positive mode ESI-mass spectra and originates from the $\left[\mathrm{Mn}_{2} \mathrm{~L}^{1}(\mathrm{OAC})_{2}\left(\mathrm{CH}_{3} \mathrm{CN}\right)\right]^{+}$monocation. Other peaks generated during the electrospray correspond to the exchange of $\mathrm{AcO}^{-}$by $\mathrm{HCO}_{2}^{-}\left(\left[\mathrm{Mn}_{2} \mathrm{~L}^{1}(\mathrm{OAc})\left(\mathrm{HCO}_{2}\right)\right]^{+}, \mathrm{m} / \mathrm{z}=757.2\right)$ and the loss of $\mathrm{Mn}(\mathrm{OAc})_{2}\left(\left[\mathrm{MnL}^{1} \mathrm{H}\right]^{+}, \mathrm{m} / \mathrm{z}=598.2\right)$. Complex 7 affords a mass spectrum with the major peak at $m / z=755.1\left(\left[\mathrm{Mn}_{2} \mathrm{~L}^{2}(\mathrm{OAc})_{2}\left(\mathrm{H}_{2} \mathrm{O}\right)\right]^{+}\right)$and two minor peaks that can be assigned to 
$\left[\mathrm{Mn}_{2} \mathrm{~L}^{2}(\mathrm{OAc})\right]^{+}$at $\mathrm{m} / \mathrm{z}=678.1$ and $\left[\mathrm{MnL}^{2} \mathrm{Na}\right]^{+}$at $\mathrm{m} / \mathrm{z}=587.1$. The isotopic patterns of these peaks match very well their simulated spectra. In addition, negative ion ESI-mass spectrum of complex 6 shows only one peak at $m / z=319$ corresponding to $\mathrm{BPh}_{4}{ }^{-}$anion, in agreement with the molar conductivity of $129 \Omega^{-1} \mathrm{~cm}^{2} \mathrm{~mol}^{-1}$ for 6 in methanol, a value expected for a complex that behaves as a 1:1 electrolyte in solution.

Figure 1(b) illustrates the X-band EPR spectra of the two powdered complexes at $120 \mathrm{~K}$. These spectra exhibit two features, one around $g=2$ which dominates the spectra and a low-field component at $g=5$ for 6 and 6.8 for 7 , which can be associated with spin transitions in $S>1 / 2$ spin states of the weakly coupled phenolate-bridged $\mathrm{Mn}(\mathrm{II}) \mathrm{Mn}(\mathrm{III})$ center, as already observed for other $\mathrm{Mn}(\mathrm{II}) \mathrm{Mn}(\mathrm{III})$ complexes [29-30].

The electronic spectra of complexes 6 and 7 (Figure 1(c)) recorded in DMF exhibit an intense absorption at 275 and $279 \mathrm{~nm}$, respectively, assigned to $\pi-\pi^{*}$ transitions within the ligands, and two moderately intense bands in the region $330-550 \mathrm{~nm}$ attributed to ligand-to-metal charge transfer $(L M C T)$ transitions from pr orbital of phenolate (either bridging or terminal phenolate) to partially filled $d \sigma^{*}$ and $d \pi^{*}$ orbitals of $M n(I I I)[17,19,31,32]$ with an additional contribution of carboxylate-to-Mn(III) CT on the lower energy band [33]. The low intensity broad band observed around $608 \mathrm{~nm}\left(\varepsilon=265 \mathrm{M}^{-1} \mathrm{~cm}^{-1}\right)$ for 6 and at $698 \mathrm{~nm}\left(\varepsilon=294 \mathrm{M}^{-1} \mathrm{~cm}^{-1}\right)$ for 7 , corresponds to d-d transitions of the $\mathrm{Mn}(\mathrm{III})$ ion in agreement with reported values for related $\mathrm{Mn}(\mathrm{II}) \mathrm{Mn}(\mathrm{III})$ complexes [31,34]. The red shift of the $\mathrm{d}-\mathrm{d}$ band can be interpreted in terms of the effect of the axial or equatorial position of the terminal phenolate group in the two complexes (Figure 2). The more distant binding of phenolate to the $\mathrm{Mn}(\mathrm{III})$ ion on the elongation Jean-Teller axis weakens the metal-phOax bond reducing the $d$-d energy gap and this can account for red shift of this band in the spectrum of 7 relative to 6 [35]. The contribution of other electronic transitions disable direct comparison of the energy of the phenolate-to-Mn(III) CT bands. Electronic spectra of the two complexes registered at different times after preparing the DMF solutions (up to $24 \mathrm{~h}$ ), showed identical molar absorption coefficients, indicating that both are stable in this solvent. 
(a)

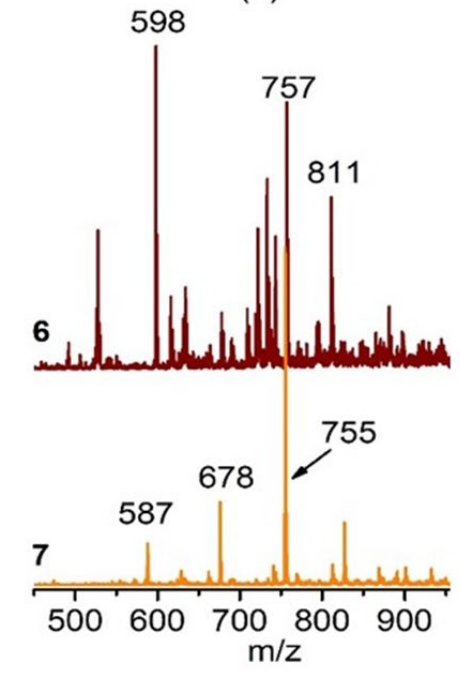

(c)

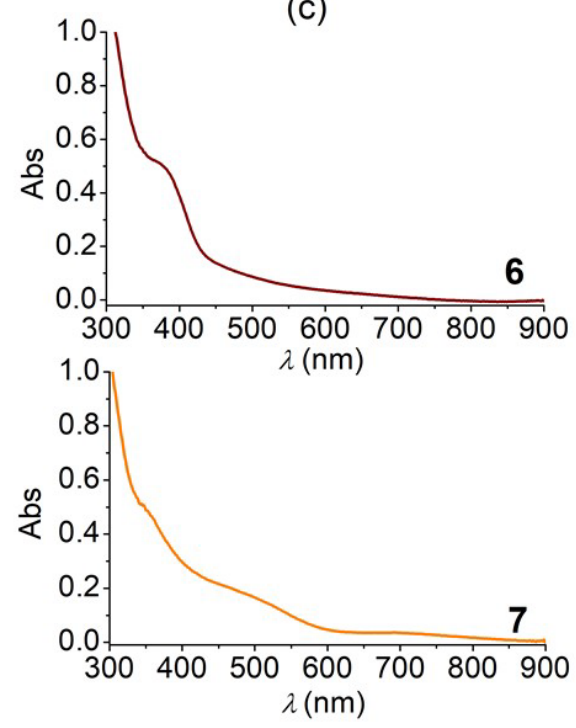

(b)

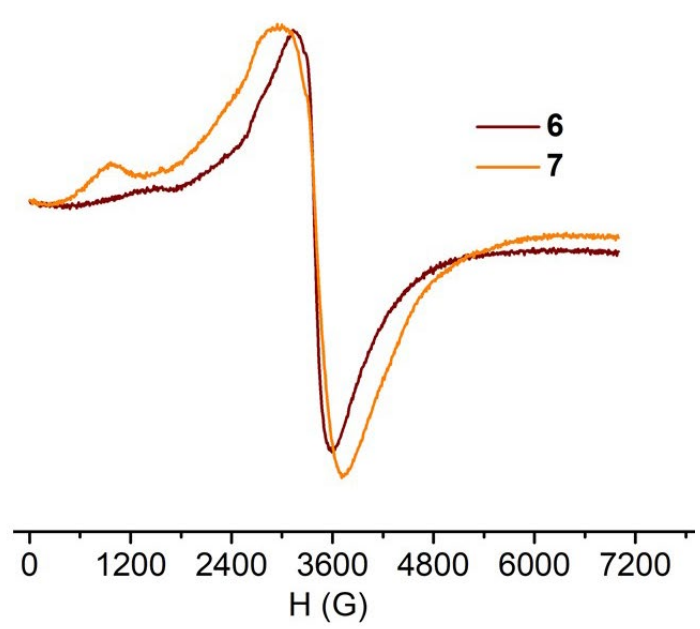

(d)

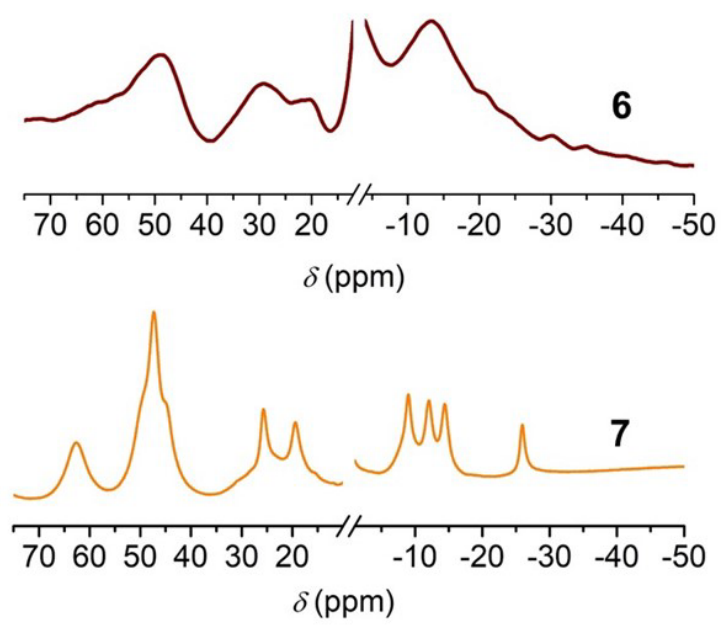

Figure 1. (a) ESI-mass spectra of 6 and 7, in MeCN, positive mode. (b) EPR spectra of solid complexes, $v=9.5 \mathrm{GHz}, T=120 \mathrm{~K}$, microwave power $=0.5 \mathrm{~mW}$. (c) Electronic spectra of 6 and 7 in DMF. [complex] $=0.125 \mathrm{mM} ; I=1 \mathrm{~cm}$. (d) ${ }^{1} \mathrm{H}$ NMR spectra of 6 in $\mathrm{DCCl}_{3}$ and 7 in $\mathrm{CD}_{3} \mathrm{OD}$. [complex] $=15 \mathrm{mM}$.

The ${ }^{1} \mathrm{H}$ NMR spectrum of solutions of 6 and 7 (Figure 1(d)) show resonances outside the diamagnetic region spanning from 70 to $-30 \mathrm{ppm}$. For the two complexes the signals appear in the same spectral region according to a weak magnetic coupling between the metal ions; however, resonances are much narrower for 7 as a consequence of the different spatial 
arrangement of the ligands in the two compounds. For $\mathbf{6}$, the spectral pattern comprises a set of broad signals at $60,48,29,20$ and $-13 \mathrm{ppm}$ (linewidth in the range of 2500 to $3500 \mathrm{~Hz}$ ) ascribed to phenolate/pyridine ring protons with even broader peaks of methylene protons spanning the full spectral range [36]. For 7, the spectrum is better resolved showing intense resonances at $62,49,47$ and $45 \mathrm{ppm}\left(\mathrm{w}_{1 / 2}=1200 \mathrm{~Hz}\right)$, and relatively sharp resonances at 26, 19, $-9,-12$ and $-14.5 \mathrm{ppm}\left(\mathrm{w}_{1 / 2}=600 \mathrm{~Hz}\right)$, and $-26 \mathrm{ppm}\left(\mathrm{w}_{1 / 2}=300 \mathrm{~Hz}\right)$. These peaks can be attributed to phenol and pyridine ring protons shifted down- and upfield as a consequence of spin-delocalization and dipolar effects, the last playing an important role in this kind of mixedvalence $\mathrm{Mn}(\mathrm{II}) \mathrm{Mn}(\mathrm{III})$ complexes [37].

The 1-10 ppm region of the ${ }^{1} \mathrm{H}$ NMR spectra of the complexes (Figure S2) show peaks belonging to the solvent, and $\mathrm{BPh}_{4}^{-}$in the case of complex 6 , without traces of the ligand, indicating the compounds are stable towards metal dissociation. Besides, no signal attributable to terminally coordinated acetate (broad signal at around $1.9 \mathrm{ppm}$ [38]) is observed, which suggests that the most plausible structure for the two complexes in solution contains two bridging acetate ligands as shown in Figure 2.
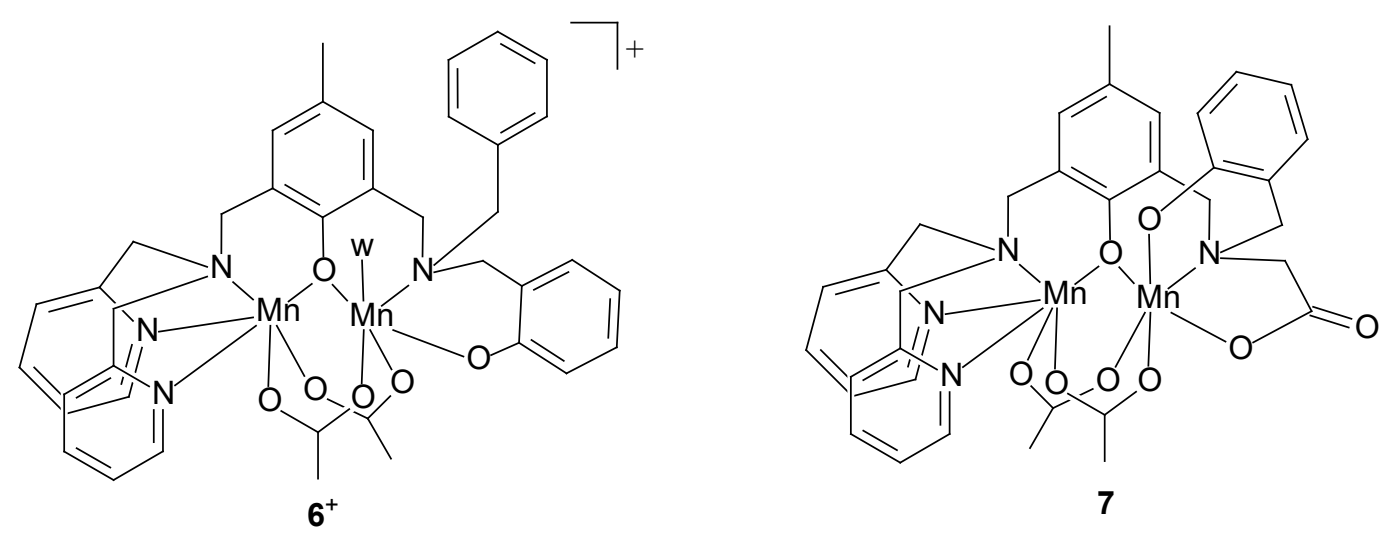

Figure 2. Schematic structure formulas of the diMn complexes under study. $w=$ water

\subsection{Electrochemical studies}

The electrochemical properties of complexes $\mathbf{6}$ and $\mathbf{7}$ were investigated by cyclic voltammetry in DMF solutions containing 0.1 $\mathrm{M} \mathrm{Bu}_{4} \mathrm{NPF}_{6}$ (Figure S3). The two complexes exhibit one quasireversible reduction wave at $E_{1 / 2}=0.058 \mathrm{~V}(6)$ and $-0.164 \mathrm{~V}(7)$. Linear voltammetry confirmed 
that these waves correspond to reduction processes. $W_{1 / 2}$ values of $0.12 \mathrm{~V}$ for 6 and $0.13 \mathrm{~V}$ for 7 in the square-wave voltammetry (SWV) experiments (Figure S3(a-b)) suggest that these reductions correspond to one-electron processes and may be attributed to the $\mathrm{Mn}(\mathrm{II}) \mathrm{Mn}(\mathrm{III}) / \mathrm{Mn}(\mathrm{II}) \mathrm{Mn}(\mathrm{II})$ redox couple.

On the oxidative side, 6 shows two anodic waves at $E_{\mathrm{pa} 1}=0.44 \mathrm{~V}$ (from deconvolution of the SWV wave) and $E_{1 / 2(2)}=0.54 \mathrm{~V}$ vs $\operatorname{SCE}\left(\Delta E_{p}=0.14 \mathrm{~V}\right)$ (Figure S3(c)). These two one-electron oxidation processes might correspond to the formation of $\mathrm{Mn}(\mathrm{III})_{2}$ and $\mathrm{Mn}(\mathrm{II}) \mathrm{Mn}(\mathrm{III})$-phenoxyl radical. The formation of $\mathrm{Mn}(\mathrm{II}) \mathrm{Mn}(\mathrm{III})$-phenoxyl radical and $\mathrm{Mn}(\mathrm{III})_{2}$ occurs at close potentials and are difficult to distinguish [39]. However, the growth of the relative intensity of the second oxidation wave with increasing scan rate suggests it corresponds to the ligand-centered oxidation to generate a $\mathrm{Mn}(\mathrm{II}) \mathrm{Mn}(\mathrm{III})$-phenoxyl radical [40]. In the case of complex 7, three nonreversible anodic processes are detected at $E_{\mathrm{pa} 1} \approx 0.4 \mathrm{~V}, E_{\mathrm{pa} 2} \approx 0.52 \mathrm{~V}$ and $E_{\mathrm{pa} 3} \approx 0.79 \mathrm{~V} \mathrm{vs}$ SCE (Figure S3(d)), which might be attributed to the formation of higher oxidation state complexes with concomitant formation of oxo-bridges. It must be observed that while reduction and first oxidation processes of 6 take place at potentials differing in $0.38 \mathrm{~V}, 7$ shows electrochemical stability over $\Delta E=0.56 \mathrm{~V}$. Therefore, the introduction of carboxylate instead of the non-coordinating benzyl group in the ligand framework plays a significant role in the stabilization of the mixed valence $\mathrm{Mn}(\mathrm{II}) \mathrm{Mn}(\mathrm{III})$ state in dry DMF. An still larger $\Delta \mathrm{E}(0.965 \mathrm{~V})$ was reported for another triply phenolate-bis(acetate)-bridged $\mathrm{Mn}(\mathrm{II}) \mathrm{Mn}(\mathrm{III})$ complex where the benzyl group is replaced by pyridine, a donor stronger than carboxylate, with redox processes taking place at $E_{\text {red }}=-0.057 \mathrm{~V}$ and $E_{\mathrm{ox}}=0.908 \mathrm{~V}$ vs SCE in MeCN [19].

\subsection{Catalase activity studies}

3.3.1. Kinetics. In the previous sections it was shown that the replacement of the noncoordinating benzyl arm by the carboxylate in the ligand influences both the ligand-field splitting and the redox potentials. Thus, it is expected that this ligand changes also affect the catalase activity of the resulting complexes. The ability of complexes 6 and 7 to catalyze $\mathrm{H}_{2} \mathrm{O}_{2}$ disproportion was tested in DMF, $\mathrm{CH}_{3} \mathrm{CN}$, and $\mathrm{CH}_{3} \mathrm{OH}$. For both complexes, an immediate 
vigorous evolution of dioxygen was observed after addition of $\mathrm{H}_{2} \mathrm{O}_{2}$ to a solution of the catalyst. Turnovers as high as 3600 without significant decomposition were measured for the two complexes in DMF, and up to 600 and 300 equivalents of $\mathrm{H}_{2} \mathrm{O}_{2}$ were decomposed in $\mathrm{CH}_{3} \mathrm{CN}$ and $\mathrm{CH}_{3} \mathrm{OH}$, respectively. Besides, in the last two solvents, the rate of $\mathrm{O}_{2}$ evolution diminished after successive additions of $\mathrm{H}_{2} \mathrm{O}_{2}$. It is likely that the bridging ligands of the complexes serve as internal bases facilitating deprotonation of the peroxide coupled to the redox reaction. Therefore, in DMF, a non protic solvent $\left(\alpha_{\mathrm{DMF}}=0\right)$ [41], these catalysts disproportionate $\mathrm{H}_{2} \mathrm{O}_{2}$ with only slight loss of activity (Figure S4). However, in the protic $\mathrm{CH}_{3} \mathrm{OH}$ solvent $\left(\alpha_{\mathrm{MeOH}}=0.93\right)$ or $\mathrm{CH}_{3} \mathrm{CN}$, a solvent with intermediate proton donor ability $\left(\alpha_{\mathrm{MeCN}}=0.19\right)$, protonation of the bridges could inactivate the catalyst resulting in moderate to low turnover numbers. Therefore, DMF was chosen as solvent for evaluation of catalase activity.

The initial rate of $\mathrm{H}_{2} \mathrm{O}_{2}$ disproportionation by complexes 6 and 7 in DMF was measured as a function of the complex (Figure S5) and substrate concentrations at $25^{\circ} \mathrm{C}$. As shown in Figure 3 , for both complexes, at constant $\left[\mathrm{H}_{2} \mathrm{O}_{2}\right]_{0}=148 \mathrm{mM}$, the initial rate $\left(r_{\mathrm{i}}\right)$ varies linearly with the [catalyst], and the first-order rate constants $k_{1}^{6}=24.5(3) \mathrm{min}^{-1}$ and $k_{1}^{7}=51.2(2) \mathrm{min}^{-1}$ were obtained from the slope of the straight line.

At constant [catalyst] $=0.25 \mathrm{mM}$, complexes 6 and 7 exhibit saturation kinetics with $\left[\mathrm{H}_{2} \mathrm{O}_{2}\right]_{0}$ (Figure 3 ) and the $r_{i} /\left[\right.$ catalyst] vs $\left[\mathrm{H}_{2} \mathrm{O}_{2}\right]_{0}$ data could be fitted to the Michaelis-Menten equation (eq. 1). In this equation, $k_{c a t}$ is the catalytic rate constant (turnover number) and $K_{M}$ is a measure of the complex affinity for $\mathrm{H}_{2} \mathrm{O}_{2}$ (the lower the $K_{M}$ value, the higher affinity for $\mathrm{H}_{2} \mathrm{O}_{2}$ ). The values of catalytic turnover numbers $k_{c a t}^{6}=2.3(1) \mathrm{s}^{-1}$ and $k_{c a t}^{7}=1.22(2) \mathrm{s}^{-1}$, and Michaelis constants $K_{M}^{6}=6.8(4) \times 10^{-1} \mathrm{M}$ and $K_{M}^{7}=7.3(5) \times 10^{-2} \mathrm{M}$, were determined from the non-linear fit of experimental data to eq. 1 (solid wine and blue lines in Figure 3).

$$
\frac{r_{i}}{\text { [catalyst }]}=\frac{k_{\text {cat }}\left[\mathrm{H}_{2} \mathrm{O}_{2}\right]}{K_{M}+\left[\mathrm{H}_{2} \mathrm{O}_{2}\right]}
$$


Kinetics results show that electron transfer between 6 and $\mathrm{H}_{2} \mathrm{O}_{2}$ is more effective (larger $k_{\text {cat }}$ ) than for 7 , but 6 is 10 -times less efficient at binding the substrate $\left(K_{M}^{6}>K_{M}^{7}\right)$, so that can reach a maximal rate $\left(V_{\max }=k_{\text {cat }}\right.$ [catalyst] $)$ at $\left[\mathrm{H}_{2} \mathrm{O}_{2}\right]$ much higher than 7 . Based on the $k_{\text {cat }} / K_{\mathrm{M}}$ criterion, $\frac{k_{c a t}^{6}}{K_{M}^{6}}=3.38 \mathrm{M}^{-1} \mathrm{~s}^{-1}$ and $\frac{k_{c a t}^{7}}{K_{M}^{7}}=16.7 \mathrm{M}^{-1} \mathrm{~s}^{-1}$, the catalytic efficiency of 7 is $\approx 5$-times higher than for complex 6 . The higher efficiency of 7 to disproportionate $\mathrm{H}_{2} \mathrm{O}_{2}$ is related to its larger affinity for binding peroxide, probably because the presence of the terminal carboxylate facilitates $\mathrm{H}_{2} \mathrm{O}_{2}$ binding through hydrogen bonding favoring the formation of the catalyst $-\mathrm{H}_{2} \mathrm{O}_{2}$ adduct $[18,42]$.
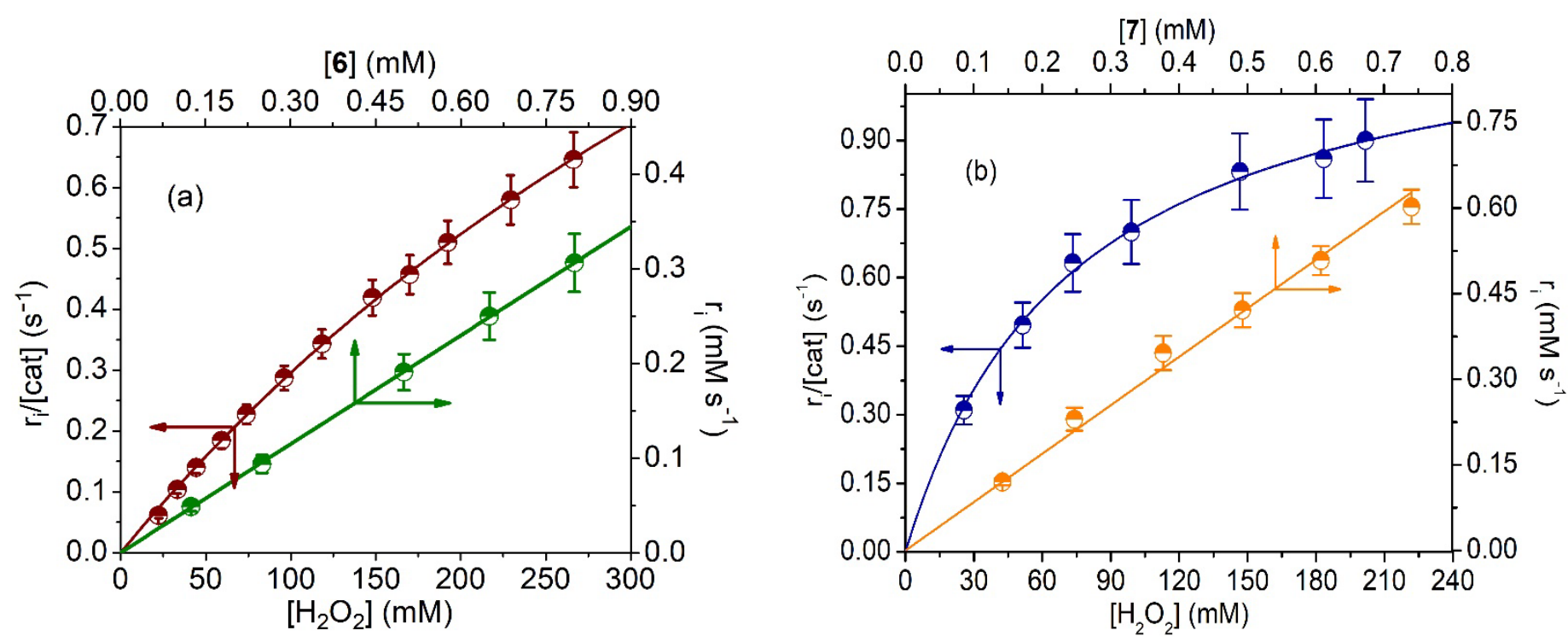

Figure 3. Effect of [catalyst] (green and orange lines; $\left[\mathrm{H}_{2} \mathrm{O}_{2}\right]=148 \mathrm{mM}$ ) and $\left[\mathrm{H}_{2} \mathrm{O}_{2}\right]_{0}$ (brown and blue lines; [catalyst] $=0.25 \mathrm{mM}$ ) on the initial rate of $\mathrm{H}_{2} \mathrm{O}_{2}$ disproportionation catalyzed by (a) 6 and (b) 7 at $298 \mathrm{~K}$, in DMF

3.3.2. Spectroscopic Monitoring of the Catalase Reaction. In order to get insight into the mechanism of the $\mathrm{H}_{2} \mathrm{O}_{2}$ disproportionation catalyzed by complexes 6 and 7 in DMF, the reaction was monitored by using a combination of electronic and EPR spectroscopies and ESIMS. UV-visible absorption spectra taken in DMF during the progress of the reaction of complex 6 with excess $\mathrm{H}_{2} \mathrm{O}_{2}$ exhibited an increase of the absorption band at $275 \mathrm{~nm}$ concurrently with the decrease of the absorbance at $365 \mathrm{~nm}$ (Figure 4(a)) with an isosbestic point at $322 \mathrm{~nm}$. 
The intensity of bands at longer wavelengths changed slightly during the reaction. The same spectral changes were observed upon successive additions of 100 equiv of $\mathrm{H}_{2} \mathrm{O}_{2}$ to the DMF solution of the catalyst, and the $\mathrm{O}_{2}$ production rate measured after each new addition was essentially constant, suggesting that the catalyst is stable in these reaction conditions.

(a)

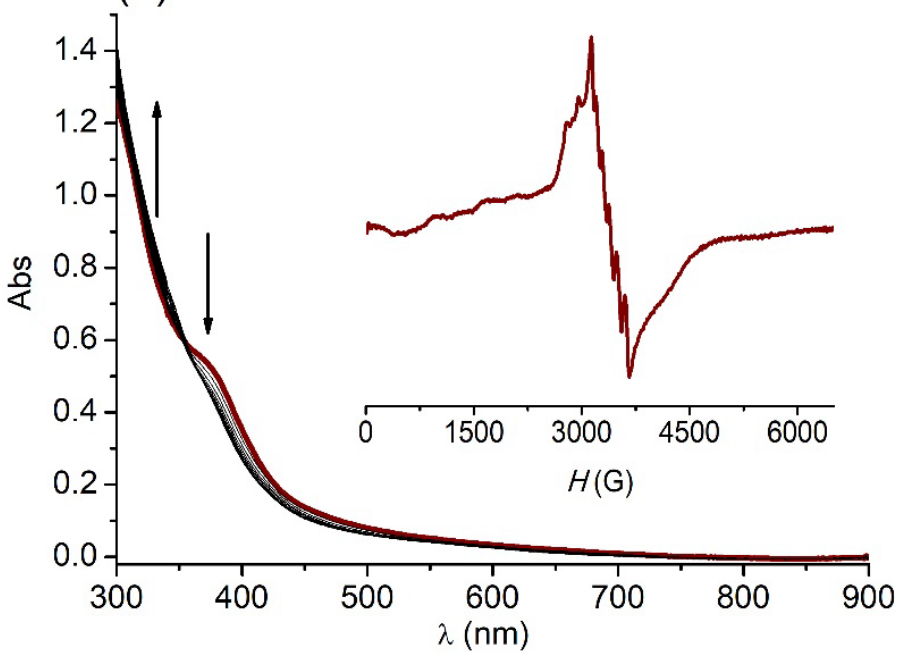

(b)

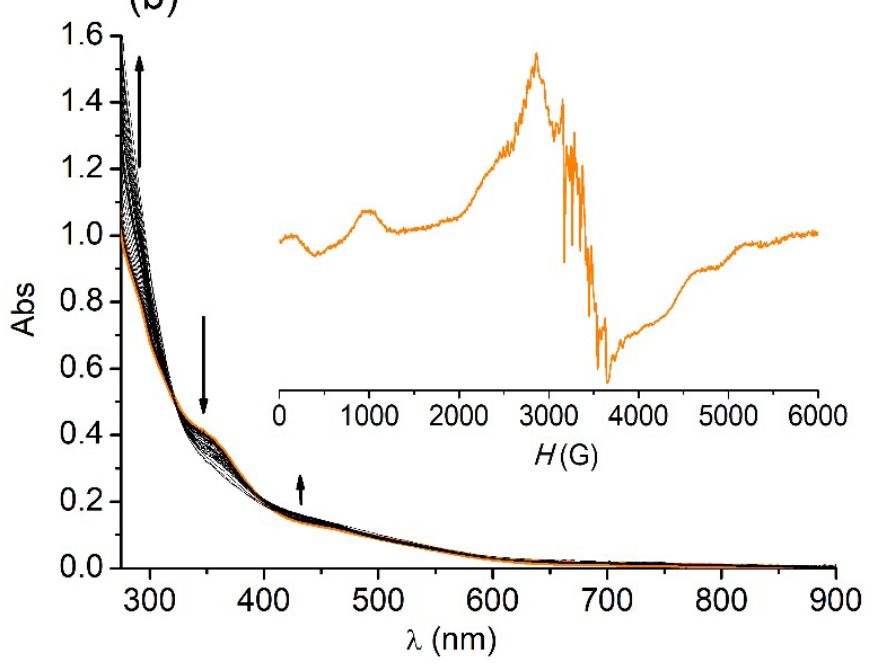

Figure 4. UV-vis spectra of (a) $6(0.125 \mathrm{mM})$ and (b) $7(0.1 \mathrm{mM})$ after addition of 100 equiv. of $\mathrm{H}_{2} \mathrm{O}_{2}$, in DMF. $T=25^{\circ} \mathrm{C}$. Inset: X-band EPR spectra of $1 \mathrm{mM}$ catalyst +100 equiv. $\mathrm{H}_{2} \mathrm{O}_{2}$ a few minutes after mixing. $v=9.5 \mathrm{GHz}, T=110 \mathrm{~K}$, microwave power $=0.5 \mathrm{~mW}$.

After addition of 100 equiv. of $\mathrm{H}_{2} \mathrm{O}_{2}$ to a solution of 6 in DMF, the low-temperature X-band EPR spectra exhibit a broad signal (Figure 4(a), inset) consistent with a weakly coupled Mn(II)Mn(III) center [17] overlapped to a six-line signal centered at $g=2$ with hyperfine splitting of $\approx 93 \mathrm{G}$. This 6-line signal departs from that of the solvated $\mathrm{Mn}^{2+}$ ion and is characteristic of a $\mathrm{Mn}(\mathrm{II})$ center bound to the ligand that could arise from a $\mathrm{Mn}(\mathrm{III}) \mathrm{Mn}(\mathrm{II})$ species where the phenolatebridge disrupted through protonation $[36,37]$. This cleavage of the phenolate bridge makes the diMn unit appear as the individual ions: an EPR silent $\mathrm{Mn}$ (III) and a mononuclear $\mathrm{Mn}$ (II) with a six-line signature. This was confirmed by addition of $p$-toluensulphonic acid to the solution of 6 in DMF giving the same EPR spectrum. This spectral pattern was kept at the end of the reaction. Retention of the complex nuclearity during the reaction was confirmed by mass spectrometry. ESI-mass spectra obtained after addition of 100 equiv $\mathrm{H}_{2} \mathrm{O}_{2}$ to a DMF solution 
of 6 showed the parent peak at $\mathrm{m} / \mathrm{z} 811.2$ and other peaks already appearing in the spectrum of the starting solution and a new peak at $\mathrm{m} / \mathrm{z} 773.2$ corresponding to $\left[\mathrm{Mn}_{2} \mathrm{~L}^{1}(\mathrm{OAc})\left(\mathrm{HCO}_{2}\right)(\mathrm{OH})\right]^{+}$(Figure S6(a)), thus providing a clear indication that the diMn complex persisted during the catalytic cycle.

During the spectrophotometric monitoring of the reaction of 7 with excess $\mathrm{H}_{2} \mathrm{O}_{2}$ in $\mathrm{DMF}$, the intensity of the $C T$ band at $345 \mathrm{~nm}$ decreased and absorbance at $279 \mathrm{~nm}$ grew up, with an isosbestic point at $323 \mathrm{~nm}$ (Figure 4(b)). Interestingly, the intensity of the band at $462 \mathrm{~nm}$ (PhOto-d $\pi \mathrm{Mn}(\mathrm{III}) \mathrm{CT}$ ) also raised, although in a lesser proportion. These spectral changes suggest a different arrangement of phenolate groups around $\mathrm{Mn}(\mathrm{III})$ during catalysis. For this complex, the initial intensity of the $L M C T$ bands was not restored at the end of the $\mathrm{H}_{2} \mathrm{O}_{2}$ disproportionation reaction. The EPR spectra taken during the $7+\mathrm{H}_{2} \mathrm{O}_{2}$ reaction course (Figure 4(b), inset) showed broad lines expanded over the whole spectral range characteristic of diMn(II) species with weak anti-ferromagnetic exchange interactions $[37,43,44]$ which originate from the contribution of the populated paramagnetic higher excited spin states [45]. Several sets of 11 lines are observed on the top of some of the more intense signals (i.e. signal centered at $2870 \mathrm{G}$ ), with an average hyperfine splitting of $\approx 43 \mathrm{G}$ typical of the interaction between the electronic spin and two $\mathrm{Mn}(\mathrm{II})$ nuclear spins $\left(I_{\mathrm{Mn}}=5 / 2\right)$. This $\mathrm{Mn}(\mathrm{II})_{2}$ spectrum is superimposed to a 6 -line signal at $\mathrm{g} \approx 2$ that arises from a small fraction of monomeric aqueous $\mathrm{Mn}^{2+}$ (up to $5 \%$ at the end of the reaction). The final EPR spectrum of the reaction mixture was identical to those registered during the reaction meaning the formed $\mathrm{Mn}(\mathrm{II})_{2}$ species persists in solution, in agreement with absorption spectra. The disproportionation of $\mathrm{H}_{2} \mathrm{O}_{2}$ catalyzed by 7 was also followed by ESI-MS. Besides the parent peak at m/z 755 and other peaks already present in the starting complex solution, another intense peak is observed at $\mathrm{m} / \mathrm{z}=619.1$ that can be attributed to $\left[\mathrm{Mn}_{2} \mathrm{~L}^{2}\right]^{+}$, thus confirming the retention of dinuclearity of the complex during catalysis (Figure S6(b)).

3.3.3. Mechanism of the CAT-like reaction of 6 and 7. The two complexes catalyze $\mathrm{H}_{2} \mathrm{O}_{2}$ disproportionation with first order kinetics on [catalyst], rates are essentially constant upon 
successive additions of $\mathrm{H}_{2} \mathrm{O}_{2}$, and $\mathrm{O}_{2}$ evolution occurs without a time-lag at the onset of the reaction, all suggesting these complexes are responsible for the disproportionation of $\mathrm{H}_{2} \mathrm{O}_{2}$. Based on spectroscopic results, both compounds retain their dinuclearity during catalysis but employ a different redox cycle for $\mathrm{H}_{2} \mathrm{O}_{2}$ disproportionation. From the EPR spectra, the mixed valence $\mathrm{Mn}(\mathrm{II}) \mathrm{Mn}(\mathrm{III})$ complex 6 is present in solution during the catalytic cycle either in the coupled $[\mathrm{Mn}(\mathrm{II})(\mu-\mathrm{PhO}) \mathrm{Mn}(\mathrm{III})]^{+}$or uncoupled $[\mathrm{Mn}(\mathrm{II})(\mathrm{PhOH}) \mathrm{Mn}(\mathrm{III})]^{2+}$ forms. A possible mechanism is presented in Scheme 2, including the equilibrium of the uncoupled/coupled diMn species of $\mathbf{6}$ (observed in the EPR spectra) and species present in the ESI-mass spectra. It is proposed that $\mathbf{6}$ is the active reduced form of the catalyst that reacts with $\mathrm{H}_{2} \mathrm{O}_{2}$ in the slow reductive half-reaction (turnover-limiting step). The observation of saturation kinetics with substrate indicates that a catalyst-peroxide adduct is formed at this step, probably by substitution of the labile solvent molecule bound to $\mathrm{Mn}(\mathrm{III})$, which upon $\mathrm{O}-\mathrm{O}$ bond breaking yields the $\mu$-oxo-Mn(III)Mn(IV) and water. This oxidized form of the complex reacts with another $\mathrm{H}_{2} \mathrm{O}_{2}$ molecule in a fast-oxidative half-reaction to afford $\mathrm{O}_{2}$ and restores the starting complex closing the cycle. This oxidative half-reaction must be much faster than the reductive one, so that the $\mu-0 x o-M n(I I I) M n(I V)$ is not observed by EPR.

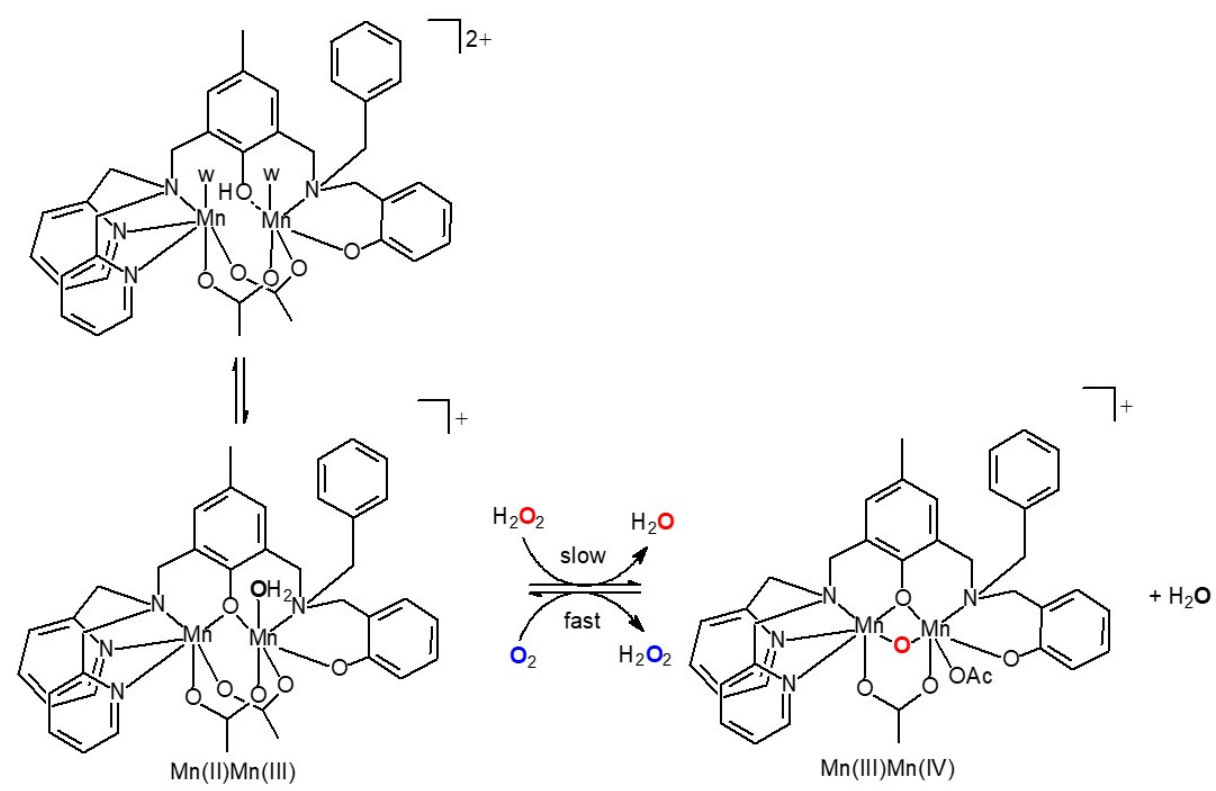

Scheme 2. Proposed catalytic cycle for complex 6 
For $\mathrm{H}_{2} \mathrm{O}_{2}$ disproportionation catalyzed by complex 7 , the observation of a coupled $\mathrm{Mn}(\mathrm{II})_{2}$ species in the EPR spectra taken during and at the end of the reaction suggests a redox cycle involving $\mathrm{Mn}(\mathrm{II})_{2}$ and $\mathrm{Mn}(\mathrm{III})_{2}$ oxidation states, as proposed in Scheme 3.

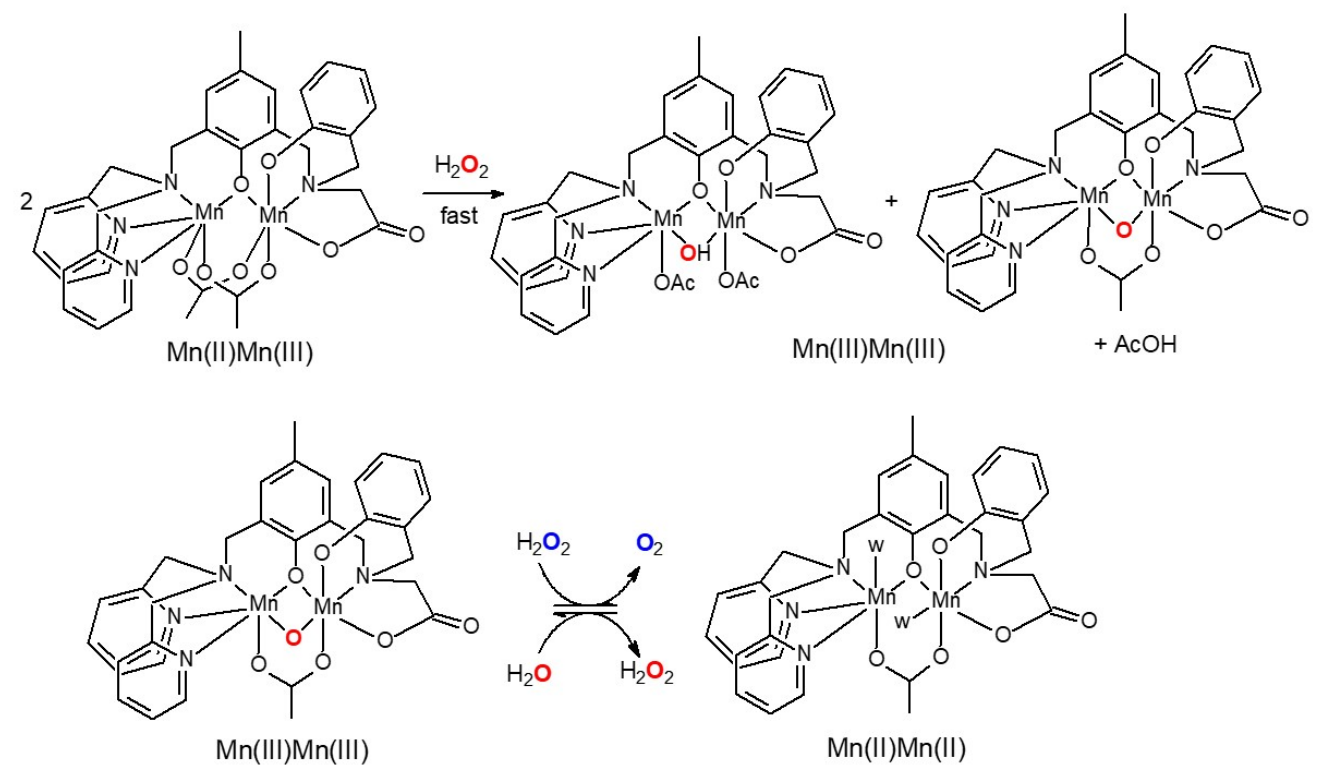

Scheme 3. Proposed catalytic cycle for complex 7

According to this scheme, initial oxidation of the starting $\mathrm{Mn}(\mathrm{II}) \mathrm{Mn}(\mathrm{III})$ complex by $\mathrm{H}_{2} \mathrm{O}_{2}$ affords $\mathrm{Mn}(\mathrm{III})_{2}(\mathrm{OAc})_{1(2)}(\mu-\mathrm{O}(\mathrm{H}))$ species (EPR silent) in a fast step. In this way, the starting complex should be a precursor of the active complex. A similar one-electron oxidation of a precursor phenolate-bridged diMn(II) complex has already been reported [36]. The $\mathrm{H}_{2} \mathrm{O}_{2}$ binding to the starting complex can take place through acetate-shift to yield the $\mu$-hydroxo-Mn(III $)_{2}$ species, where terminally bound acetate can be further protonated and partially dissociates. The higher labilizing effect of $L^{2(3-)}$ compared to $L^{1(2-)}$ may favor acetate dissociation as evidenced by the high proportion of the $\mathrm{Mn}_{2} \mathrm{~L}^{+}$species in the mass spectra. The $\mu$-oxo- $\mathrm{Mn}(\mathrm{III})_{2}$ species is proposed to be the oxidized active form of the catalyst that enters the catalytic cycle of $\mathrm{H}_{2} \mathrm{O}_{2}$ dismutation. The absence of a lag-time at the onset of the reaction is consistent with the oxidation of the mixed valence complex being faster than the $\mathrm{H}_{2} \mathrm{O}_{2}$ disproportionation reaction. Hydrogen bond to the terminally bound carboxylate group of the ligand within the catalyst $-\mathrm{H}_{2} \mathrm{O}_{2}$ 
adduct (Figure S7) may account for the higher efficiency of this complex for binding peroxide (low $K_{M}$ value) which renders 7 more efficient to catalyze $\mathrm{H}_{2} \mathrm{O}_{2}$ disproportionation than 6 .

At $\mathrm{pH}$ 7, the electrochemical potentials for the two-electron $\mathrm{O}_{2} / \mathrm{H}_{2} \mathrm{O}_{2}$ and $\mathrm{H}_{2} \mathrm{O}_{2} / \mathrm{H}_{2} \mathrm{O}$ redox couples are $+0.04 \mathrm{~V}$ and $+1.11 \mathrm{~V}$ vs $S C E$, respectively. If disproportionation of $\mathrm{H}_{2} \mathrm{O}_{2}$ occurs through an outer-sphere mechanism, only diMn complexes with redox couples between the $\mathrm{H}_{2} \mathrm{O}_{2}$ reduction and oxidation potentials should be active. However, a number of complexes that exhibit redox potentials outside the $\mathrm{H}_{2} \mathrm{O}_{2}$ dismutation range react efficiently $[7,14]$, suggesting diMn complexes dismutate $\mathrm{H}_{2} \mathrm{O}_{2}$ through an inner-sphere mechanism with electron transfer taking place within the catalyst-peroxide adduct, in agreement with the saturation kinetics observed for a number of diMn mimics. In Table 1 , the catalytic efficiency $\left(k_{\text {cat }} / K_{\mathrm{M}}\right.$ values) of complexes $\mathbf{6}$ and $\mathbf{7}$ is compared to other phenolate-bridged diMn complexes of ligands with different terminal $\mathrm{N} / \mathrm{O}$ donors that employ either $\mathrm{Mn}(\mathrm{II})_{2} / \mathrm{Mn}(\mathrm{III})_{2}$ or $\mathrm{Mn}(\mathrm{II}) \mathrm{Mn}(\mathrm{III}) / \mathrm{Mn}(\mathrm{III}) \mathrm{Mn}(\mathrm{IV})$ redox cycles during catalysis. For those complexes with low affinity for the substrate (large $K_{M}$ value) that do not achieve saturation with $\left[\mathrm{H}_{2} \mathrm{O}_{2}\right]$, second-order rate constants $\left(k_{2 c a t}\right)$ are given for comparison, considering that when $K_{M} \gg\left[\mathrm{H}_{2} \mathrm{O}_{2}\right]$, the denominator of eq. 1 is dominated by $K_{\mathrm{M}}$, and $r_{\mathrm{i}}=\frac{k_{\text {cat }}}{K_{M}}$ [catalyst] $\left[\mathrm{H}_{2} \mathrm{O}_{2}\right]=k_{2 \text { cat }}$ [catalyst] $\left[\mathrm{H}_{2} \mathrm{O}_{2}\right]$. The catalytic efficiency of triply bridged ( $\mu$-phenolate)bis $\left(\mu_{1,3}\right.$-carboxylate)diMn complexes falls into two groups. Complexes bearing terminal carboxylate that react with efficiency higher than $11 \mathrm{M}^{-1} \mathrm{~s}^{-1}$ (entries 1-2), and those with pyridyl/phenolate arms that react with efficiency lower than $5 \mathrm{M}^{-1} \mathrm{~s}^{-1}$ (entries 4-6), highlighting the role of carboxylate to facilitate the formation of the adduct with $\mathrm{H}_{2} \mathrm{O}_{2}$ through hydrogen bond. Phenolate-bridged $\left[\mathrm{Mn}_{2} \mathrm{~L}(\mathrm{OH})_{2}\left(\mathrm{H}_{2} \mathrm{O}\right)_{2}\right.$ ] with no acetate bridges but four carboxylate arms, is placed in between these two groups, with the carboxylate groups compensating the long intermetallic separation that disfavors the cooperativity between the two $\mathrm{Mn}$ ions for the electron transfer process (entry 3$)$. $\operatorname{Bis}(\mu-$ phO)diMn complexes are even less efficient than any of the ( $\mu$-phenolate)bis $\left(\mu_{1,3^{-}}\right.$ carboxylate)diMn complexes, one example is shown in entry 7 . Enhanced activity is observed when the two $\mathrm{Mn}$ ions are linked by one or two alcoholate bridges (entries 8-9) where the intermetallic distance is shorter than in the phenolate-bridged complexes. As can be observed 
in Table 1, the Mn $\cdots$ Mn separation in phenolate-bridged complexes is longer than $3.4 \AA$, while in the $(\mu \text {-alcoholate })_{\mathrm{n}}$ diMn complexes the $\mathrm{Mn} \cdots \mathrm{Mn}$ distance is closer to the value reported for the enzyme ( 3.03 and $3.18 \AA$ for the oxidized and reduced forms, respectively, entry 10 ), strengthening the cooperativity between the two Mn ions.

Table 1. Catalytic efficiency of phenolate-bridged diMn complexes for disproportionating $\mathrm{H}_{2} \mathrm{O}_{2}$

\begin{tabular}{|c|c|c|c|c|c|c|c|}
\hline & Complex & $\begin{array}{l}\mathrm{k}_{\mathrm{cat}} / \mathrm{K}_{\mathrm{M}} \text { or } \\
\mathrm{k}\left(\mathrm{M}^{-1} \mathrm{~s}^{-1}\right)\end{array}$ & Bridging ligands & $\begin{array}{l}\text { Ligand terminal } \\
\text { groups }\end{array}$ & Redox cycle & $\begin{array}{c}\mathrm{Mn} \cdots \mathrm{Mn} \\
(\AA)\end{array}$ & Refs \\
\hline 1 & 7 & 16.7 & $(\mu-\mathrm{phO})(\mu-\mathrm{OAc})_{2}$ & $\mathrm{py}_{2} / \mathrm{phO}^{-}, \mathrm{CO}_{2}^{-}$ & $\mathrm{Mn}(\mathrm{II})_{2} / \mathrm{Mn}(\mathrm{III})_{2}$ & - & This work \\
\hline 2 & {$\left[\mathrm{Mn}_{2}(\mathrm{bcpmp})(\mu-\mathrm{OAc})_{2}\right]$} & 11.44 & $(\mu-\mathrm{phO})(\mu-\mathrm{OAc})_{2}$ & py, $\mathrm{CO}_{2}^{-1}$ py, $\mathrm{CO}_{2}^{-}$ & $\mathrm{Mn}(\mathrm{II}) \mathrm{Mn}(\mathrm{III}) / \mathrm{Mn}(\mathrm{III}) \mathrm{Mn}(\mathrm{IV})$ & 3.47 & [17] \\
\hline 3 & {$\left[\mathrm{Mn}_{2} \mathrm{~L}(\mathrm{OH})_{2}\left(\mathrm{H}_{2} \mathrm{O}\right)_{2}\right]$} & $5.08^{a}$ & $(\mu$-phO) & $\left(\mathrm{CO}_{2}^{-}\right)_{2} /\left(\mathrm{CO}_{2}^{-}\right)_{2}$ & $\mathrm{Mn}(\mathrm{II})_{2} / \mathrm{Mn}(\mathrm{III})_{2}$ & $3.67^{d}$ & [18] \\
\hline 4 & {$\left[\mathrm{Mn}_{2}(\mathrm{bphpmp})(\mu-\mathrm{OAc})_{2}\left(\mathrm{H}_{2} \mathrm{O}\right)\right]^{+}$} & $4.7^{\mathrm{b}}$ & $(\mu-\mathrm{phO})(\mu-\mathrm{OAc})_{2}$ & $\mathrm{py}_{2} / \mathrm{py}, \mathrm{phO}^{-}$ & NR & 3.497 & [19] \\
\hline 5 & {$\left[\mathrm{Mn}_{2}(\mathrm{bpbp})(\mu-\mathrm{OAc})_{2}\right]^{2+}$} & 3.76 & $(\mu-\mathrm{phO})(\mu-\mathrm{OAc})_{2}$ & $\mathrm{py}_{2} / \mathrm{py}_{2}$ & $\mathrm{Mn}(\mathrm{II}) \mathrm{Mn}(\mathrm{III}) / \mathrm{Mn}(\mathrm{III}) \mathrm{Mn}(\mathrm{IV})$ & 3.45 & {$[17,46]$} \\
\hline 6 & 6 & 3.38 & $(\mu-\mathrm{phO})(\mu-\mathrm{OAc})_{2}$ & $\mathrm{py}_{2} / \mathrm{phO}^{-}$ & $\mathrm{Mn}(\mathrm{II}) \mathrm{Mn}(\mathrm{III}) / \mathrm{Mn}(\mathrm{III}) \mathrm{Mn}(\mathrm{IV})$ & - & This work \\
\hline 7 & {$\left[\mathrm{Mn}_{2}(\mathrm{bphba})_{2}(\mathrm{Cl})_{2}\right]$} & 1.1 & $(\mu-\mathrm{phO})_{2}$ & $\mathrm{py}_{2} / \mathrm{py}_{2}$ & $\mathrm{Mn}(\mathrm{II})_{2} / \mathrm{Mn}(\mathrm{III})_{2}$ & 3.41 & {$[47,48]$} \\
\hline 8 & {$\left[\mathrm{Mn}_{2}(\mathrm{HBPCINOL})(\mathrm{BPClNOL}) \mathrm{Cl}\right]^{+}$} & $80.2^{\mathrm{c}}$ & $(\mu$-phO $)(\mu-\mathrm{OR})$ & py, $\mathrm{RO}^{-} / \mathrm{py}, \mathrm{phO}^{-}$ & $\mathrm{Mn}(\mathrm{II}) \mathrm{Mn}(\mathrm{III}) / \mathrm{Mn}(\mathrm{III}) \mathrm{Mn}(\mathrm{IV})$ & 3.16 & [30] \\
\hline 9 & {$\left[\mathrm{Mn}_{2}(\mu-\mathrm{OMe})(\mathrm{OAc})(\text { hppentO) }]^{+}\right.$} & 106.3 & $(\mu-\mathrm{OR})_{2}(\mu-\mathrm{OAc})$ & py,phO-/py,phO- & $\mathrm{Mn}(\mathrm{II})_{2} / \mathrm{Mn}(\mathrm{III})_{2}$ & 2.95 & [49] \\
\hline 10 & MnCAT (T. thermophilus) & $3.1 \times 10^{6}$ & $(\mu-\mathrm{OH})\left(\mu-\mathrm{OH}_{2}\right)(\mu-\mathrm{OAc})$ & $\mathrm{His}, \mathrm{Glu} / \mathrm{His}, \mathrm{Glu}, \mathrm{H}_{2} \mathrm{O}$ & $\mathrm{Mn}(\mathrm{II})_{2} / \mathrm{Mn}(\mathrm{III})_{2}$ & $3.18 ; 3.03$ & {$[50,51,13]$} \\
\hline & $\begin{array}{l}\text { NR }=\text { not reported. Bc } \\
\text { 2,6-bis }\{\text { [bis(2-pyridylmethyl)amino]n } \\
\text { 2-[bis(2-pyridylmethyl)aminomethyl] }\end{array}$ & $\begin{array}{l}\text { mp } \quad= \\
\text { ethyl\}-4-tert } \\
6-\{[(2-\text {-hydrc }\end{array}$ & $\begin{array}{l}\text { 2,6-bis }(\{(\text { carboxymethyl) } \\
\text { butylphenol; bphba }= \\
\text { xybenzyl)(2-pyridylmethyl }\end{array}$ & $\begin{array}{l}\text { (1-pyridyl)methyl]amin } \\
\text { 2-\{(N,N-bis(2-pyridylm } \\
\text { amino]methyl\}-4-methy }\end{array}$ & $\begin{array}{l}\text { methyl)-4-methylphenol]; } \\
\text { thyl)amino)methyl\}phenol; } \\
\text { shenol; } \quad \mathrm{LH}_{4}\end{array}$ & $\begin{aligned} \mathrm{pbp} & = \\
\mathrm{hpmp} & = \\
& =\end{aligned}$ & \\
\hline
\end{tabular}

\section{Conclusions}

Unsymmetrical $\mathrm{N}_{4} \mathrm{O}_{2}$-Hexadentate $\mathrm{H}_{2} \mathrm{~L}^{1}$ and $\mathrm{N}_{4} \mathrm{O}_{3}$-heptadentate $\mathrm{NaH}_{2} \mathrm{~L}^{2}$ ligands afford mixed valence $\mathrm{Mn}(\mathrm{II}) \mathrm{Mn}(\mathrm{III})$ complexes 6 and 7 where each $\mathrm{Mn}$ ion is in a different coordination environment. Both complexes share the coordination sphere of the $\mathrm{Mn}(\mathrm{II})$ ion, but differ in the donor groups surrounding $\mathrm{Mn}(\mathrm{III})$. In 6, the sixth coordination position of $\mathrm{Mn}(\mathrm{III})$ is occupied by a water molecule, while in $7 \mathrm{Mn}(\mathrm{III})$ is bound to the $\mathrm{NO}_{3}$-donor sites of the ligand and two additional $\mathrm{O}$-atoms from bridging acetates, leaving this metal ion coordinatively saturated. The replacement of the non-coordinating benzyl arm of $L^{1}$ by the carboxylate arm in $L^{2}$ modifies the 
ligand field splitting, the reduction potential and the reactivity of the resulting complex. Therefore, complex $\mathbf{7}$ catalyzes $\mathrm{H}_{2} \mathrm{O}_{2}$ disproportionation more efficiently than $\mathbf{6}$, even when the formation of the catalyst-peroxide adduct must take place through acetate-shift in 7 but by direct replacement of a labile solvent molecule in $\mathbf{6}$. This different reactivity can be interpreted in terms of the larger affinity of 7 for the substrate (smaller $K_{M}$ value), attributed to the ability of the terminal carboxylate group of the ligand to stabilize the adduct through hydrogen bond to $\mathrm{H}_{2} \mathrm{O}_{2}$, and to the higher labilizing effect of the heptadentate ligand that favors the acetate-shift. These two combined effects in 7 render $K_{\mathrm{M}}=0.073 \mathrm{M}$, that compares well to $K_{\mathrm{M}}=0.083 \mathrm{M}$ of MnCAT of $T$. thermophilus [50], and, based on the $k_{\text {cat }} / K_{M}$ criterion, place complex 7 as the most efficient among the phenolate-bridged diMn catalysts. Given that acetate-shift is also an initial process in the phosphohydrolase activity [52], further catalytic studies of complexes 6 and 7 as hydrolase mimics will be undertaken to test the bifunctionality of these complexes.

\section{Declaration of competing interest}

The authors declare that they have no known competing financial interests or personal relationships that could have appeared to influence the work reported in this paper.

\section{Acknowledgments}

This work was supported by the National University of Rosario (PIP-BIO553) and the Consejo Nacional de Investigaciones Científicas y Técnicas (CONICET, PIP 0337 and PUE 0068), the

Centre National de la Recherche Scientifique (CNRS, PICS 07121), and the Agency for Science, Technology and Innovation of Santa Fe (ASACTel, IO 2010-164-16). R. Mehrotra thanks CONICET for a post-doctoral fellowship.

\section{Appendix A. Supplementary data}

Supplementary data to this article can be found online at https://doi.org/10.1016/j.jinorgbio.2020.xxxxx

\section{References}

[1] B. Yang, Y. Chen, J. Shi, Chem. Rev. 119 (2019) 4881-4985. 
[2] J. E. Penner-Hahn, in Manganese Redox Enzymes, ed. V. L. Pecoraro, VCH, New York, 1992.

[3] D. Salvemini, C. Muscoli, D. P. Riley, S. Cuzzocrea, Pulm. Pharmacol. Ther. 15 (2002) 439-447.

[4] J. M. McCord, M. A. Edeas, Biomed. Pharmacother. 59 (2005) 139-142.

[5] A. Mahammed, Z. Gross, Catal. Sci. Technol. 1 (2011) 535-540.

[6] C. Policar, in: J. S. Reboucas, I. Batinic-Haberle, I. Spasojevic, D. S. Warner, D. St. Clair (Eds.), Redox Active Therapeutics, Springer, Berlin, 2016, pp. 125-164.

[7] S. Signorella, C. Palopoli, G. Ledesma, Coord. Chem. Rev. 365 (2018) 75-102.

[8] Y. Ning, Y. Huo, H. Xue, Y. Du, Y. Yao, A. C. Sedgwick, H. Lin, C. Li, S.-D. Jiang, B.-W. Wang, S. Gao, L. Kang, J. L. Sessler, J.-L. Zhang, J. Am. Chem. Soc. 142 (2020) 10219-10227.

[9] P. J. Riggs-Gelasco, R. Mei, J. E. Penner-Hahn, H. H. Thorp, V. L. Pecoraro (Eds.), Mechanistic Bioinorganic Chemistry, American Chemical Society, Washington, DC, 1995 (Chapter 8).

[10] W. C. Stallings, K. A. Pattridge, R. A. Strong, M. L. Ludwig, J. Biol. Chem. 260 (1985) 16424-16432.

[11] S. Signorella, C. Palopoli, V. Daier, G. Ledesma, R.H. Kretsinger, E.A. Permyakov, V.N. Uversky (Eds.), Encyclopedia of Metalloproteins, Springer, New York, 2013, pp. 1283-1292.

[12] V. V. Barynin, M.M. Whittaker, S. V. Antonyuk, V. S. Lamzin, P. M. Harrison, P. J. Artymyuk, J. M. Whittaker, Structure 9 (2001) 725-738.

[13] S. V. Antonyuk, W. R. Melik-Adamiyan, V. R. Popov, V. S. Lamzin, P. D. Hempstead, P. M. Harrison, P. J. Artymiuk, V. V. Barynin, Crystallogr. Rep. 45 (2000) 105-116.

[14] S. Signorella, C. Hureau, Coord. Chem. Rev. 256 (2012) 1229-1245.

[15] A. J. Wu, J. E. Penner-Hahn, V. L. Pecoraro, Chem. Rev. 104 (2004) 903-938. 
[16] S. Abdolahzadeh, J. W. de Boer, W.R. Browne, Eur. J. Inorg. Chem. (2015) 34323456.

[17] R. Singh, M. Haukka, C. J. McKenzie, E. Nordlander, Eur. J. Inorg. Chem. (2015) 3485-3492.

[18] V. Solís, C. Palopoli, V. Daier, E. Rivière, F. Collin, D. Moreno, C. Hureau, S. Signorella, J. Inorg. Biochem. 182 (2018) 29-36.

[19] P. Karsten, A. Neves, A.J. Bertoluzzi, J. Strahle, C. Maichle-Mossmer, Inorg. Chem. Commun. 5 (2002) 434-438.

[20] L. Dubois, R. Caspar, L. Jacquamet, P.-E. Petit, M.-F. Charlot, C. Baffert, M. -N. Collomb, A. Deronzier, J.-M. Latour, Inorg. Chem. 42 (2003) 4817-4827.

[21] G. N. Ledesma, E. Anxolabéhère-Mallart, L. Sabater, C. Hureau, S. R. Signorella, J. Inorg. Biochem. 186 (2018) 10-16.

[22] A. Neves, M. A. de Brito, V. Drago, K. Griesar, W. Haase, Inorg. Chim. Acta 237 (1995) 134-135.

[23] E. Lambert, B. Chabut, S. Chardon-Noblat, A. Deronzier, G. Chottard, A. Bousseksou, J.-P. Tuchagues, J. Laugier, M. Bardet, J.-M. Latour, J. Am. Chem. Soc. 119 (1997) 9424-9437.

[24] L. L. Koh, J. O. Ranford, W. T. Robinson, J. O. Svensson, A. L. C. Tan, D. Wu, Inorg. Chem. 35 (1996) 6466-6472.

[25] C. Belle, G. Gellon, C. Scheer, J. L. Pierre, Tetrahedron Lett. 35 (1994) 7019-7022.

[26] R. N. Salvatore, C. H. Yoon, K. W. Jung, Tetrahedron 57 (2001) 7785-7811.

[27] B. Capon, W. G. Overend, M. Sobell, Tetrahedron 1961 (16) 106-112

[28] C. Palopoli, G. Gómez, A. Foi, F. Doctorovich, S. Mallet-Ladeira, C. Hureau, S. Signorella, J. Inorg. Biochem. 167 (2017) 49-59.

[29] A. Gelasco, M. L. Kirk, J. W. Kampf, V. L. Pecoraro, Inorg. Chem. 36 (1997) 18291837. 
[30] R. O. Costa, S. S. Ferreira, C. A. Pereira, J. R. Harmer, C. J. Noble, G. Schenk, R. W. A. Franco, J. A L. C. Resende, P. Comba, A. E. Roberts, C. Fernandes, A. Horn Jr, Front. Chem. 6 (2018) 491. doi: 10.3389/fchem.2018.00491.

[31] R. Lomoth, P. Huang, J. Zheng, L. Sun, L. Hammarström, B. Akermark, S. Styring, Eur. J. Inorg. Chem. (2002) 2965-2974.

[32] C. Hureau, L. Sabater, F. Gonnet, G. Blain, J. Sainton, E. Anxolabéhère-Mallart, Inorg. Chim. Acta 359 (2006) 339-345.

[33] M. M. Whittaker, C. A. Ekberg, R. A. Edwards, E. N. Baker, G.B. Jameson, J.W. Whittaker, J. Phys. Chem. B 102 (1998) 4668-4677.

[34] H. Diril, H.-R. Chang, M. J. Nilges, X. Zhang, J. A. Potenza, H. J. Schugar, S. S. Isied, D. N. Hendrickson, J. Am. Chem. Soc. 111 (1989) 5102-5114.

[35] M. G. Patch, K. P. Simolo, C. J. Carrano, Inorg. Chem. 21 (1982) 2972-2977.

[36] L. Dubois, D.-F. Xiang, X.-S. Tan, J.-M. Latour, Eur. J. Inorg. Chem. (2005) 15651571.

[37] L. Dubois, D.-F. Xiang, X.-S. Tan, J. Pécaut, P. Jones, S. Baudron, L. Le Pape, J.M. Latour, C. Baffert, S. Chardon-Noblat, M.-N. Collomb, A. Deronzier, Inorg. Chem. 42 (2003) 750-760.

[38] A. E. M. Boelrijk, G. C. Dismukes, Inorg. Chem. 39 (2000) 3020-3028.

[39] T. Kurahashi, A. Kikuchi, T. Tosha, Y. Shiro, T. Kitagawa, H. Fujii, Inorg. Chem. 47 (2008) 1674-1686.

[40] T.K. Paine, T. Weyhermüller, E. Bothe, K. Weighardt, P. Chandhuri, Dalton Trans. (2003) 3136-3144.

[41] Shorter, J. Correlation Analysis of Organic Reactivity; Research Studies Press: New York, 1983; pp 146-153.

[42] L. Dubois, J. Pecaut, M.-F. Charlot, C. Baffert, M.-N. Collomb, A. Deronzier, J.-M. Latour, Chem. Eur. J. 14 (2008) 3013-3025.

[43] C. Hureau, L. Sabater, E. Anxolabéhère-Mallart, M. Nierlich, M.-F. Charlot, F. Gonnet, E. Rivière, G. Blondin, Chem. Eur. J. 10 (2004) 1998-2010. 
C. Hureau, S. Blanchard, M. Nierlich, G. Blain, E. Rivière, J.-J. Girerd, E. Anxolabéhère-Mallart, G. Blondin, Inorg. Chem. 43 (2004) 4415-4426.

[45] S. Blanchard, G. Blain, Eric Rivière, M. Nierlich, G. Blondin, Chem. Eur. J. 9 (2003) 4260-4268.

[46] Y. Gultneh, Y. T. Tesema, T. B. Yisgedu, R. J. Butcher, G. Wang, G. T. Yee, Inorg. Chem. 45 (2006) 3023-3033.

[47] N. Reddig, D. Pursche, M. Kloskowski, C. Slinn, S. M. Baldeau, A. Rompel, Eur. J. Inorg. Chem. (2004) 879-887.

[48] S. Signorella, A. Rompel, K. Büldt-Karentzopoulos, B. Krebs, V. L. Pecoraro, J.-P. Tuchagues, Inorg. Chem. 46 (2007) 10864-10868.

[49] H. Biava, C. Palopoli, C. Duhayon, J.-P. Tuchagues, S. Signorella, Inorg. Chem. 48 (2009) 3205-3214.

[50] M. Shank, V. Barynin, G. Dismukes, Biochemistry 33 (1994) 15433-15436.

[51] V. V. Barynin, P. D. Hempstead, A. A. Vagin, S. V. Antonyuk, W. R. MelikAdamyan, V. S. Lamzin, P. M. Harrison, P. J. Artymiuk, J. Inorg. Biochem. 67 (1997) 196.

[52] S. J. Smith, M. J. Riley, C. J. Noble, G. R. Hanson, R. Stranger, V. Jayaratne, G. Cavigliasso, G. Schenk, L. R. Gahan, Inorg. Chem. 48 (2009) 10036-10048. 